\title{
Synthesis and Antibacterial Activity of Isomeric 15-Membered Azalides
}

\author{
Sulejman Alihodzic, Andrea Fajdetic, Gabrijela Kobrehel, Gorjana Lazarevski, \\ Stjepan Mutak, Drazen Pavlovic, Vlado Stimac, Hana Cipcic, Miroslava Dominis Kramaric, \\ Vesna Erakovic, Andreja Hasenöhrl, Natasa Marsic, Wolfgang Schoenfeld
}

Received: July 14, 2006 / Accepted: November 14, 2006

(C) Japan Antibiotics Research Association

\begin{abstract}
A series of 3-keto and 3-O-acyl derivatives of both 6-O-alkyl-8a-aza-8a-homoerythromycin $\mathrm{A}$ and 6-O-alkyl-9a-aza-9a-homo-erythromycin A were synthesised and tested against Gram-positive and Gram-negative bacteria. Derivatives of 8a-aza-8a-homoerythromycin A have potent antibacterial activity against not only azithromycin-susceptible strains, but also efflux (M) and inducible macrolide-lincosamide-streptogramin $\left(\mathrm{iMLS}_{\mathrm{B}}\right)$ resistant Gram-positive pathogens, while the corresponding 9a-isomers were less active. Introduction of an additional ring such as 11,12-cyclic carbonate reduced antibacterial activity of both series. 3-Keto and 3-O-(4-nitrophenyl)acetyl derivatives of 6-O-methyl-8a-aza-8a-homoerythromycin A show typical macrolide pharmacokinetics in preliminary in vivo studies in mice, and their in vivo efficacy is demonstrated.
\end{abstract}

Keywords azalide, ketolide, acylide, antibacterial activity, structure-activity relationship

\section{Introduction}

Second-generation macrolide antibiotics such as clarithromycin [1] (6-O-methylerythromycin A) and azithromycin [2, 3] (15-membered azalide) have been widely prescribed for upper and lower respiratory tract

S. Alihodzic (Corresponding author), A. Fajdetic, G. Kobrehel, G. Lazarevski, S. Mutak, D. Pavlovic, V. Stimac, H. Cipcic, M. D. Kramaric, V. Erakovic, A. Hasenöhrl, N. Marsic, W. Schoenfeld: GSK Research Centre Zagreb Ltd., Prilaz baruna Filipovica 29, 10000 Zagreb, Croatia infections because of their superior antibacterial activity, pharmacokinetic properties and fewer gastrointestinal side effects compared to erythromycin A. However, the therapeutic utility of these macrolides has been severely compromised by the emergence of resistant pathogens [4].

The discovery that the cladinose moiety was not absolutely necessary for good antibacterial activity [5] has opened up new areas on the macrolactone ring for SAR exploration. The next generation of macrolide antibiotics, e.g. ketolides, anhydrolides and acylides, all derived from 3-O-decladinosylerythromycin A, were identified over the past decade. The ketolide telithromycin (HMR 3647) [6] has gained market approval in EU and USA and cethromycin (ABT-773) [7] is in clinical development.

In this report, we describe a novel series of 3-keto and 3-O-acyl derivatives of both $8 \mathrm{a}$-aza-8a-homoerythromycin A (8a-lactam) and 9a-aza-9a-homoerythromycin A (9alactam), that showed potent antibacterial properties against susceptible pathogens and improved activity against several species of efflux (M) and inducible ( $\mathrm{iMLS}_{\mathrm{B}}$ ) macrolide resistant Gram-positive pathogens.

\section{Chemistry}

The synthetic route to 3-keto derivatives of $9 \mathrm{a}-$ and $8 \mathrm{a}-$ lactams is presented in Fig. 1. Starting compounds for the synthesis were 6-O-alkylerythromycin A 9(E)- and $9(Z)$-oximes $[8,9]$. The Beckmann rearrangement of both oxime isomers was carried out with 4-toluenesulfonyl chloride in acetone-water solution at $0 \sim 5^{\circ} \mathrm{C}$ to give corresponding 9a- $(\mathbf{1} \mathbf{a} \sim \mathbf{c})$ and $8 \mathrm{a}-(\mathbf{2 a} \sim \mathbf{c})$ lactams. Subsequent removal of L-cladinose by treatment with aqueous $\mathrm{HCl}$ provided desired decladinosyl compounds $(\mathbf{3 a} \sim \mathbf{c}$ and $\mathbf{4 a} \sim \mathbf{c})$. A series of 3-ketolides were prepared by 


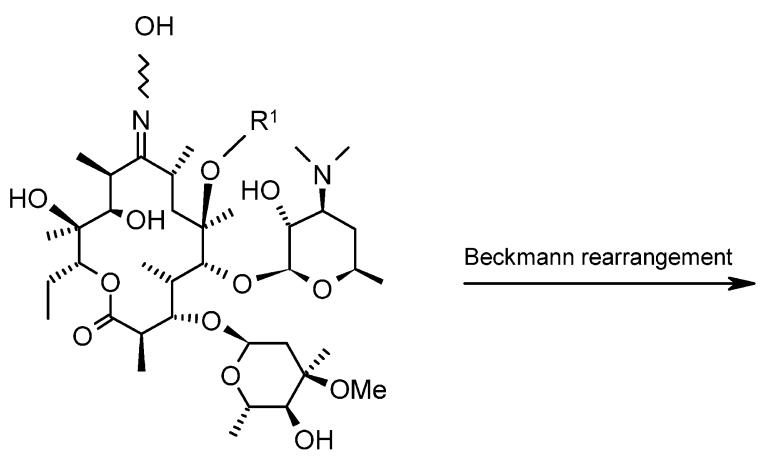

6-O-alkyl-erythromycin A 9-oximes

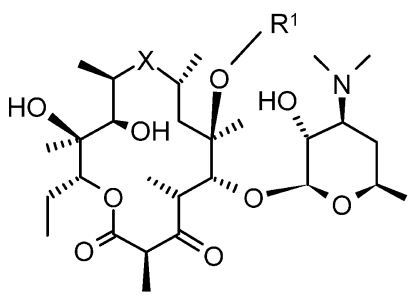

$x$

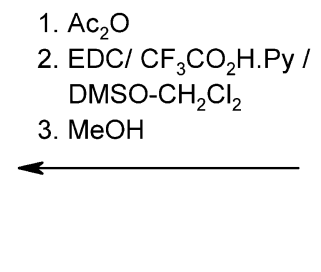

1. $\mathrm{Ac}_{2} \mathrm{O}$ $\mathrm{CO}_{2} \mathrm{H} . \mathrm{Py} /$

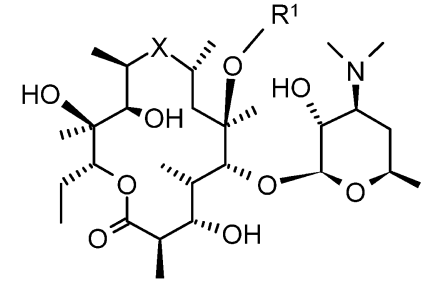

$x$

3a-c -NHCO-, Me, Et, Allyl

4a-c -CONH-, Me, Et, Allyl

5a-c -NHCO-, Me, Et, Allyl 6a-c -CONH-, Me, Et, Allyl

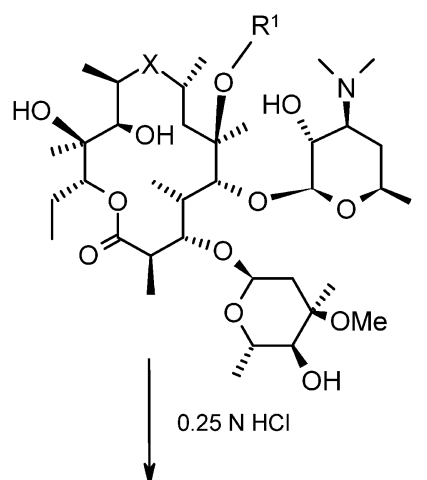

$\mathrm{X}$ $\mathrm{R}^{1}$

1a-c -NHCO-, Me, Et, Allyl 2a-c -CONH-, Me, Et, Allyl

Fig. 1 Preparation of 3-keto derivatives of 8a-aza-8a- and 9a-aza-9a-homoerythromycin A.

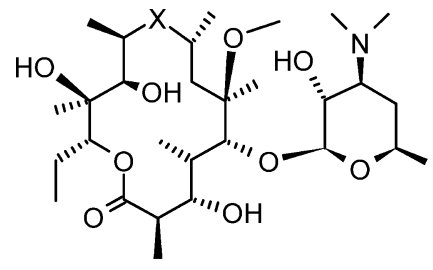

4a $\mathrm{X}=-\mathrm{CONH}-$
1. $\mathrm{Ac}_{2} \mathrm{O}$

2. $\mathrm{RCH}_{2} \mathrm{COOH} / \mathrm{PivCl}$

3. $\mathrm{MeOH}$

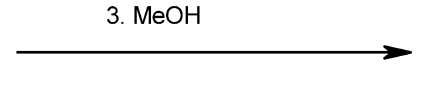

16-28 $\mathrm{X}=$-CONH-, $\mathrm{R}$ see Table 1

Fig. 2a Preparation of 3-O-acyl derivatives of 6-O-methyl-8a-aza-8a-homoerythromycin A.

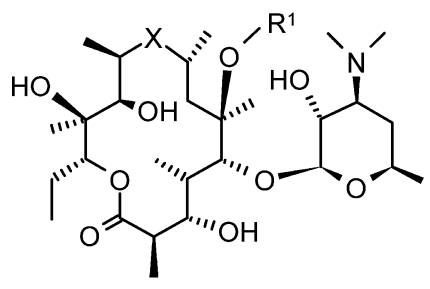

$\begin{array}{ll}\mathrm{X} & \mathrm{R}^{1}\end{array}$

3a $\quad$-NHCO-, $\mathrm{Me}$

3b -NHCO-, Et

4b -CONH-, Et $-\mathrm{CONH}-, \quad \mathrm{H}^{19)}$
1. $\mathrm{Ac}_{2} \mathrm{O}$

2. $\left(p-\mathrm{NO}_{2}-\mathrm{Ph}\right) \mathrm{CH}_{2} \mathrm{COOH} / \mathrm{PivCl}$

3. $\mathrm{MeOH}$

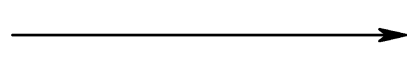

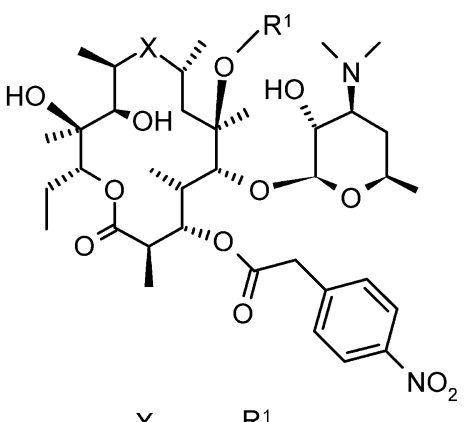

$\mathrm{X} \quad \mathrm{R}^{1}$

29 -NHCO-, $\mathrm{Me}$

30 -NHCO-, Et

31 -CONH-, Et

32 -CONH-, H

Fig. 2b Preparation of 6-O-alkyl-3-O-(4-nitrophenyl)acetyl derivatives of 8a-aza-8a- and 9a-aza-9a-homoerythromycin A. 
oxidation of 3-hydroxy group of $\mathbf{3 a} \sim \mathbf{c}$ and $4 \mathbf{a} \sim \mathbf{c}$, using acetyl as $2^{\prime}$-hydroxy-protecting group. The oxidation was performed with 1-(3-dimethylaminopropyl)-3ethylcarbodiimide hydrochloride (EDC) in the presence of pyridine trifluoroacetate. Subsequent deprotection and purification by column chromatography gave desired 3-ketolides $\mathbf{5 a} \sim \mathbf{c}$ and $\mathbf{6 a} \sim \mathbf{c}$.

Decladinosyl derivatives 3 and $\mathbf{4}$ having 2'-hydroxyprotecting group were also starting compounds for the preparation of 3-O-acyl derivatives. To prepare compounds 16 and $18 \sim 32$ mixed anhydrides, prepared from the corresponding carboxylic acid and pivaloyl chloride, were used followed by deprotection in methanol and purification by column chromatography, as shown in Fig. 2a for examples 16 and $\mathbf{1 8} \sim 28$ and Figure $2 b$ for examples 29 32. The only exception was synthesis of carbamate compound $\mathbf{1 7}$ that was prepared by reaction of $\mathbf{4 a}$ with 4-aminophenyl isocyanate.
$1 a$

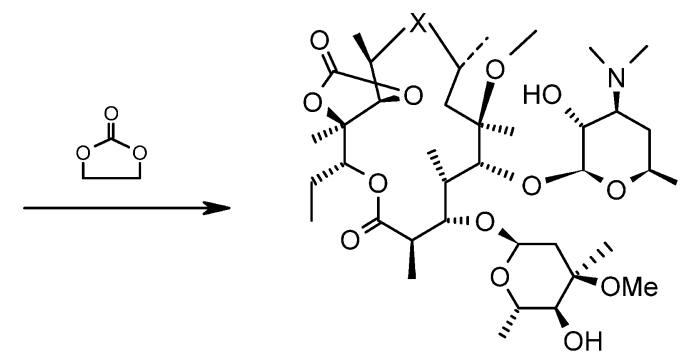

$2 a$

$7 \mathrm{X}=-\mathrm{NHCO}-$

$8 \mathrm{X}=-\mathrm{CONH}-$

$0.25 \mathrm{~N} \mathrm{HCl}$
$3 a$

$4 a$

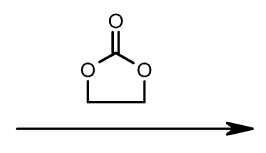

1. $\mathrm{Ac}_{2} \mathrm{O}$

2. $\mathrm{EDC} / \mathrm{CF}_{3} \mathrm{CO}_{2} \mathrm{H}$.Py / DMSO- $\mathrm{CH}_{2} \mathrm{Cl}_{2}$ 3. $\mathrm{MeOH}$

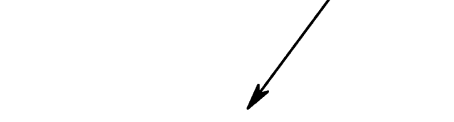

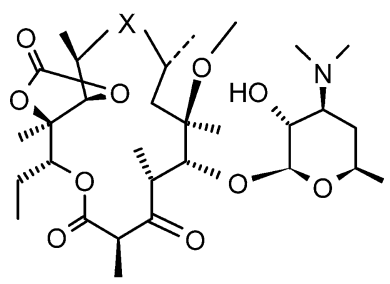

$11 \mathrm{X}=$-NHCO-

$12 \mathrm{X}=-\mathrm{CONH}-$

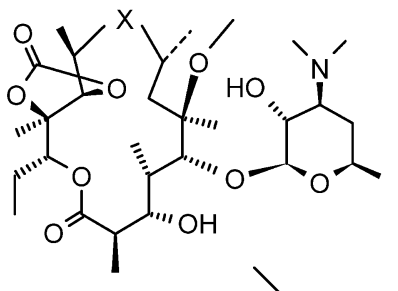

$9 \mathrm{X}=-\mathrm{NHCO}-$

$10 \mathrm{X}=-\mathrm{CONH}-$

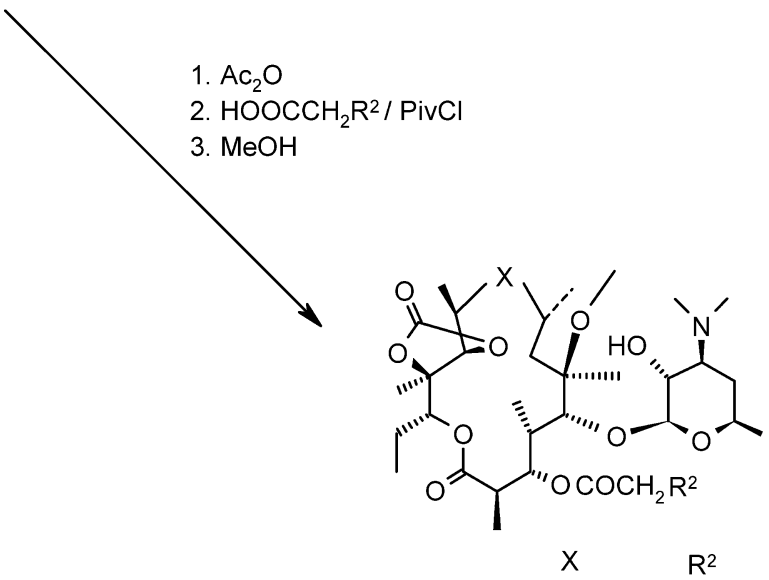

13 -NHCO-, $p-\mathrm{NO}_{2}-\mathrm{Ph}$

14 -CONH-, $p-\mathrm{NO}_{2}-\mathrm{Ph}$

15 -CONH-, $p$-Cl-Ph

Fig. 3 Preparation of 3-keto and 3-O-acyl derivatives of 6-O-methyl-8a-aza-8a- and 9a-aza-9a-homoerythromycin A 11,12cyclic carbonates. 
Table $1{ }^{13} \mathrm{C}$ NMR data for 3-O-acyl-6-O-methyl-8a-lactams

\section{Compound}

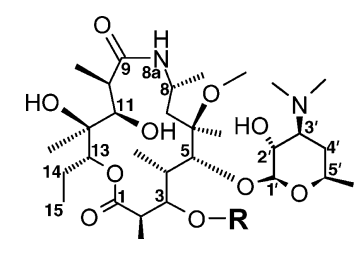

R $\delta$

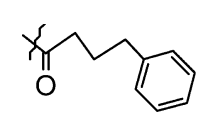

16

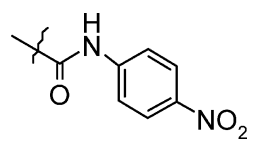

17

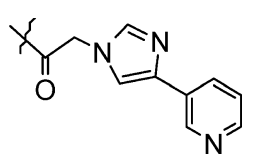

18<smiles>CC(=O)CSc1ccncc1</smiles>

19<smiles>CC(C)(C)CCc1cccc2ccccc12</smiles><smiles>[Y]C(=O)/C=C/c1ccc([N+](=O)[O-])cc1</smiles>

21<smiles>CC(C)(C)C(=O)Cc1cccnc1</smiles>

22

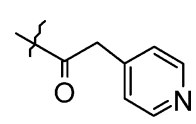

23
175.4 (C-1), 175.1 (C-9), 173.1 (3-OCO), 141.1, 128.5, 128.4, 126.1 (Ph), $103.3\left(\mathrm{C}-1^{\prime}\right), 81.8$ (C-5), 78.6 (C-6), 77.6 (C-13), 77.2 (C-3), 75.0 (C-12), 70.8 (C-11), 70.9 (C-9), 70.5 (C-2'), $69.5\left(\mathrm{C}-5^{\prime}\right), 65.9\left(\mathrm{C}-3^{\prime}\right), 51.2\left(6-\mathrm{OCH}_{3}\right)$, 43.1, $42.9(\mathrm{C}-2, \mathrm{C}-8, \mathrm{C}-10), 42.1(\mathrm{C}-7), 40.4\left[3^{\prime} \mathrm{N}\left(\mathrm{CH}_{3}\right)_{2}\right], 37.0(\mathrm{C}-4), 35.2,33.9,26.4\left(4 \times \mathrm{CH}_{2}\right), 28.8\left(\mathrm{C}-4^{\prime}\right), 23.1$ $\left(8-\mathrm{CH}_{3}\right), 21.4(\mathrm{C}-14), 21.1\left(5^{\prime}-\mathrm{CH}_{3}\right), 20.8\left(6-\mathrm{CH}_{3}\right), 16.4\left(12-\mathrm{CH}_{3}\right), 15.9\left(2-\mathrm{CH}_{3}\right), 10.9\left(14-\mathrm{CH}_{3}\right), 10.3\left(10-\mathrm{CH}_{3}\right), 9.5$ $\left(4-\mathrm{CH}_{3}\right)$.

175.9 (C-1), 175.7 (C-9), 153.6 (3-OCONH), 144.9, 143.3, 125.6, 118.0 (Ph), $103.9\left(\mathrm{C}-1^{\prime}\right), 84.0$ (C-5), 80.2 (C3), 78.9 (C-6), 77.9 (C-13), 75.7 (C-12), $71.3(\mathrm{C}-11), 71.0\left(\mathrm{C}-2^{\prime}\right), 69.4\left(\mathrm{C}-5^{\prime}\right), 66.4\left(\mathrm{C}-3^{\prime}\right), 51.4\left(6-\mathrm{OCH}_{3}\right), 43.8,(\mathrm{C}-$ 8, C-10), $43.5(\mathrm{C}-2), 42.2(\mathrm{C}-7), 40.6$ [3' $\left.\mathrm{N}\left(\mathrm{CH}_{3}\right)_{2}\right], 36.5(\mathrm{C}-4), 28.9\left(\mathrm{C}-4^{\prime}\right), 23.3\left(8-\mathrm{CH}_{3}\right), 21.8(\mathrm{C}-14), 21.3\left(5^{\prime}-\right.$ $\left.\mathrm{CH}_{3}\right), 21.0\left(6-\mathrm{CH}_{3}\right), 16.9\left(12-\mathrm{CH}_{3}\right), 16.1\left(2-\mathrm{CH}_{3}\right), 11.3\left(14-\mathrm{CH}_{3}\right), 10.9\left(10-\mathrm{CH}_{3}\right), 9.8\left(4-\mathrm{CH}_{3}\right)$.

175.2 (C-1), 174.9 (C-9), 167.7 (3-OCO), 148.5, 146.9, 132.5, 130.2, 124.0 (Py), 139.9, 139.1, 117.0 (Im), $105.1\left(\mathrm{C}-1^{\prime}\right), 85.4(\mathrm{C}-5), 80.8(\mathrm{C}-3), 77.1$ (C-6), $78.0(\mathrm{C}-13), 75.1(\mathrm{C}-12), 71.1(\mathrm{C}-11), 70.7\left(\mathrm{C}-2^{\prime}\right), 69.8\left(\mathrm{C}-5^{\prime}\right)$, $66.9\left(\mathrm{C}-3^{\prime}\right), 51.4\left(6-\mathrm{OCH}_{3}\right), 49.9\left(\mathrm{CH}_{2}\right), 43.7(\mathrm{C}-2), 43.4(\mathrm{C}-10), 43.1(\mathrm{C}-7), 42.8(\mathrm{C}-8), 40.7$ [3' $\left.\mathrm{N}\left(\mathrm{CH}_{3}\right)_{2}\right], 37.6(\mathrm{C}-$ 4), $28.8\left(\mathrm{C}-4^{\prime}\right), 23.6\left(8-\mathrm{CH}_{3}\right), 21.8(\mathrm{C}-14), 21.4\left(5^{\prime}-\mathrm{CH}_{3}\right), 21.2\left(6-\mathrm{CH}_{3}\right), 16.7\left(12-\mathrm{CH}_{3}\right), 16.1\left(2-\mathrm{CH}_{3}\right), 11.3(14-$ $\left.\mathrm{CH}_{3}\right), 10.4\left(10-\mathrm{CH}_{3}\right), 10.0\left(4-\mathrm{CH}_{3}\right)$.

174.9 (C-1), 174.7 (C-9), 168.6 (3-OCO), 149.4, 147.1, 120.6, (Py), 104.1 (C-1'), 83.9 (C-5), 79.7 (C-3), 78.4 (C6), $77.4(\mathrm{C}-13), 74.8(\mathrm{C}-12), 70.7(\mathrm{C}-11), 70.2\left(\mathrm{C}-2^{\prime}\right), 69.4\left(\mathrm{C}-5^{\prime}\right), 66.0\left(\mathrm{C}-3^{\prime}\right), 50.9\left(6-\mathrm{OCH}_{3}\right), 43.1,(\mathrm{C}-2), 42.9 \mathrm{C}-$ 10), $42.5(\mathrm{C}-8), 42.1(\mathrm{C}-7), 40.2\left[3^{\prime} \mathrm{N}\left(\mathrm{CH}_{3}\right)_{2}\right], 36.9(\mathrm{C}-4), 33.5\left(\mathrm{CH}_{2}\right), 28.6\left(\mathrm{C}-4^{\prime}\right), 23.0\left(8-\mathrm{CH}_{3}\right), 21.3(\mathrm{C}-14), 21.0$ $\left(5^{\prime}-\mathrm{CH}_{3}\right), 20.7\left(6-\mathrm{CH}_{3}\right), 16.3\left(12-\mathrm{CH}_{3}\right), 15.6\left(2-\mathrm{CH}_{3}\right), 10.8\left(14-\mathrm{CH}_{3}\right), 10.0\left(10-\mathrm{CH}_{3}\right), 9.4\left(4-\mathrm{CH}_{3}\right)$.

175.0 (C-1), 174.9 (C-9), 170.8 (3-OCO), 133.7, 131.9, 130.1, 128.5, 128.5, 128.0, 126.3, 125.8, 125.3, 124.1 (naphthyl), 103.5 (C-1'), 82.4 (C-5), 78.4 (C-6), 77.7 (C-3), 77.2 (C-13), 74.7 (C-12), 70.6 (C-11), 70.4 (C-2'), 69.2 $\left.\left(\mathrm{C}^{\prime}\right)^{\prime}\right), 65.7\left(\mathrm{C}-3^{\prime}\right), 50.9\left(6-\mathrm{OCH}_{3}\right), 43.1(\mathrm{C}-2), 42.7(\mathrm{C}-10), 42.9(\mathrm{C}-7), 42.6(\mathrm{C}-8), 40.3$ [3' $\left.\left.\mathrm{N}^{\left(\mathrm{CH}_{3}\right)}\right)_{2}\right], 39.4\left(\mathrm{CH}_{2}\right)$, $37.1(\mathrm{C}-4), 28.6\left(\mathrm{C}-4^{\prime}\right), 22.9\left(8-\mathrm{CH}_{3}\right), 21.2(\mathrm{C}-14), 21.0\left(5^{\prime}-\mathrm{CH}_{3}\right), 20.9\left(6-\mathrm{CH}_{3}\right), 16.2\left(12-\mathrm{CH}_{3}\right), 15.2\left(2-\mathrm{CH}_{3}\right), 10.7$ $\left(14-\mathrm{CH}_{3}\right), 10.1\left(10-\mathrm{CH}_{3}\right), 9.4\left(4-\mathrm{CH}_{3}\right)$.

175.2 (C-1), 174.9 (C-9), 165.4 (3-OCO), 148.6, 140.0, 128.8, 124.2 (Ph), 142.6, $122.3(\mathrm{C}=\mathrm{C}), 103.1\left(\mathrm{C}^{\prime} \mathbf{1}^{\prime}\right)$, 82.3 (C-5), 78.4 (C-6), 78.4 (C-3), 77.4 (C-13), 75.0 (C-12), $70.7(\mathrm{C}-11), 70.2\left(\mathrm{C}-2^{\prime}\right), 69.2\left(\mathrm{C}-5^{\prime}\right), 65.8\left(\mathrm{C}-3^{\prime}\right), 50.9$

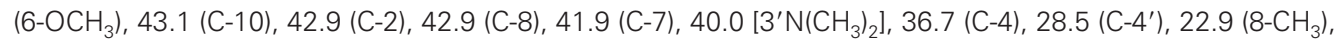
$21.3(\mathrm{C}-14), 20.9\left(5^{\prime}-\mathrm{CH}_{3}\right), 20.4\left(6-\mathrm{CH}_{3}\right), 16.3\left(12-\mathrm{CH}_{3}\right), 15.7\left(2-\mathrm{CH}_{3}\right), 10.8\left(14-\mathrm{CH}_{3}\right), 10.3\left(10-\mathrm{CH}_{3}\right), 9.4\left(4-\mathrm{CH}_{3}\right)$.

175.3 (C-1), 175.3 (C-9), 170.8 (3-OCO), 150.7, 149.1, 137.5, 130.0, 123.8 (Py), 104.3 (C-1'), 83.3 (C-5), 79.1 (C-3), 78.9 (C-6), 77.8 (C-13), 75.2 (C-12), $71.2(\mathrm{C}-11), 70.7$ (C-2'), 69.8 (C-5'), $66.5\left(\mathrm{C}-3^{\prime}\right), 51.5\left(6-\mathrm{OCH}_{3}\right), 43.6$, (C-2), $43.3 \mathrm{C}-8), 43.0(\mathrm{C}-10), 42.6(\mathrm{C}-7), 40.7\left[3^{\prime} \mathrm{N}\left(\mathrm{CH}_{3}\right)_{2}\right], 39.1\left(\mathrm{CH}_{2}\right), 37.6(\mathrm{C}-4), 28.9\left(\mathrm{C}-4^{\prime}\right), 23.5\left(8-\mathrm{CH}_{3}\right), 21.7$ $(\mathrm{C}-14), 21.5\left(5^{\prime}-\mathrm{CH}_{3}\right), 21.3\left(6-\mathrm{CH}_{3}\right), 16.7\left(12-\mathrm{CH}_{3}\right), 16.1\left(2-\mathrm{CH}_{3}\right), 11.3\left(14-\mathrm{CH}_{3}\right), 10.6\left(10-\mathrm{CH}_{3}\right), 9.9\left(4-\mathrm{CH}_{3}\right)$.

174.8 (C-1), 174.7 (C-9), 169.5 (3-OCO), 149.9, 142.5, 124.6 (Py), 103.9 (C-1'), 83.0 (C-5), 78.5 (C-6), 78.4 (C3), $77.3(\mathrm{C}-13), 74.7(\mathrm{C}-12), 70.6(\mathrm{C}-11), 70.3\left(\mathrm{C}-2^{\prime}\right), 69.4\left(\mathrm{C}-5^{\prime}\right), 65.8\left(\mathrm{C}-3^{\prime}\right), 50.9\left(6-\mathrm{OCH}_{3}\right), 43.2,(\mathrm{C}-2), 42.9 \mathrm{C}-$ 8), $42.5(\mathrm{C}-10), 42.1(\mathrm{C}-7), 40.8\left(\mathrm{CH}_{2}\right), 40.2\left[3^{\prime} \mathrm{N}\left(\mathrm{CH}_{3}\right)_{2}\right], 37.1(\mathrm{C}-4), 28.2\left(\mathrm{C}-4^{\prime}\right), 21.2(\mathrm{C}-14)$. 


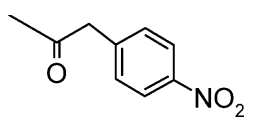

24

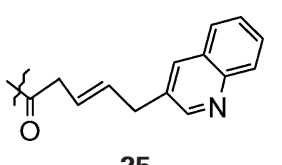

25

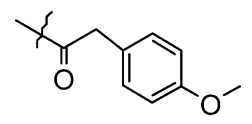

26

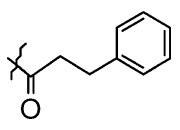

27

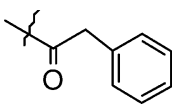

28
174.9 (C-9), 174.7 (C-1), 169.7 (3-OCO), 147.2, 141.1, 130.4, 123.7 (Ph), 104.1 (C-1'), 83.3 (C-5), 78.7 (C-3), $78.6(\mathrm{C}-13), 77.5(\mathrm{C}-6), 74.8(\mathrm{C}-12), 70.5(\mathrm{C}-11), 70.4\left(\mathrm{C}-2^{\prime}\right), 69.6\left(\mathrm{C}-5^{\prime}\right), 66.1\left(\mathrm{C}-3^{\prime}\right), 51.0\left(6-\mathrm{OCH}_{3}\right), 43.2(\mathrm{C}-2)$, $42.9(\mathrm{C}-10), 42.6(\mathrm{C}-8), 42.2(\mathrm{C}-7), 41.3\left(\mathrm{CH}_{2}\right), 40.3$ [3' $\left.\mathrm{N}\left(\mathrm{CH}_{3}\right)_{2}\right], 37.1(\mathrm{C}-4), 28.3\left(\mathrm{C}-4^{\prime}\right), 21.3(\mathrm{C}-14)$.

175.3 (C-1), 175.0 (C-9), 171.3 (3-OCO), 151.8, 147.0, 132.5, 132.3, 129.2, 128.9, 128.1, 127.4, 126.8 (Q), 134.6 $\left(\mathrm{CH}_{2} \mathrm{CH}=\mathrm{CHCH}_{2}-\mathrm{O}\right), 124.2\left(\mathrm{CH}_{2} \underline{\mathrm{CH}}=\mathrm{CHCH}_{2}-\mathrm{Q}\right), 103.5\left(\mathrm{C}-1^{\prime}\right), 82.3(\mathrm{C}-5), 78.6(\mathrm{C}-6), 77.9(\mathrm{C}-3), 77.5(\mathrm{C}-$ 13), 75.0 (C-12), $70.8(\mathrm{C}-11), 70.4\left(\mathrm{C}-2^{\prime}\right), 69.4\left(\mathrm{C}-5^{\prime}\right), 66.0\left(\mathrm{C}-3^{\prime}\right), 51.1\left(6-\mathrm{OCH}_{3}\right), 43.1,42.8(\mathrm{C}-2, \mathrm{C}-8, \mathrm{C}-10)$, 42.1 (C-7), $40.3\left[3^{\prime} \mathrm{N}\left(\mathrm{CH}_{3}\right)_{2}\right], 38.0\left(\mathrm{CH}_{2} \mathrm{CH}=\mathrm{CHCH}_{2}-\mathrm{O}\right), 36.9(\mathrm{C}-4), 36.2\left(\mathrm{CH}_{2} \mathrm{CH}=\mathrm{CHCH}_{2}-\mathrm{Q}\right), 28.7\left(\mathrm{C}-4^{\prime}\right), 23.1$ (8$\left.\mathrm{CH}_{3}\right), 21.4(\mathrm{C}-14), 21.1\left(5^{\prime}-\mathrm{CH}_{3}\right), 20.6\left(6-\mathrm{CH}_{3}\right), 16.4\left(12-\mathrm{CH}_{3}\right), 15.9\left(2-\mathrm{CH}_{3}\right), 10.9\left(14-\mathrm{CH}_{3}\right), 10.3\left(10-\mathrm{CH}_{3}\right), 9.4(4-$ $\left.\mathrm{CH}_{3}\right)$.

175.2 (C-1), 175.2 (C-9), 171.4 (3-OCO), 158.8, 130.4, 125.6, 113.8 (Ph), 103.4 (C-1'), 81.9 (C-5), 78.4 (C-6), 77.5 (C-3), 77.3 (C-13), 74.8 (C-12), 70.6 (C-11), $70.3\left(\mathrm{C}-2^{\prime}\right), 69.2\left(\mathrm{C}-5^{\prime}\right), 65.6\left(\mathrm{C}-3^{\prime}\right), 55.0\left(\mathrm{Ph}-\mathrm{OCH}_{3}\right), 50.9(6-$ $\left.\mathrm{OCH}_{3}\right), 43.0,(\mathrm{C}-8), 42.7(\mathrm{C}-2), 42.6(\mathrm{C}-10), 41.8(\mathrm{C}-7), 40.6\left(\mathrm{CH}_{2}\right), 40.1$ [3' $\mathrm{N}\left(\mathrm{CH}_{3}\right)$ ] $, 36.9(\mathrm{C}-4), 28.3\left(\mathrm{C}-4^{\prime}\right), 22.8$ $\left(8-\mathrm{CH}_{3}\right), 21.1(\mathrm{C}-14), 20.8\left(5^{\prime}-\mathrm{CH}_{3}\right), 20.6\left(6-\mathrm{CH}_{3}\right), 16.1\left(12-\mathrm{CH}_{3}\right), 15.3\left(2-\mathrm{CH}_{3}\right), 10.6\left(10-\mathrm{CH}_{3}\right), 10.0\left(14-\mathrm{CH}_{3}\right), 9.2$ $\left(4-\mathrm{CH}_{3}\right)$.

175.4 (C-1), 175.2 (C-9), 172.5 (3-OCO), 140.1, 128.5, 128.3, 126.3, (Ph), 102.7 (C-1'), 82.0 (C-5), $78.4(\mathrm{C}-6)$, $77.4(\mathrm{C}-13, \mathrm{C}-13), 75.0(\mathrm{C}-12), 70.7(\mathrm{C}-11), 70.1\left(\mathrm{C}-2^{\prime}\right), 68.7\left(\mathrm{C}-5^{\prime}\right), 65.7\left(\mathrm{C}-3^{\prime}\right), 51.0\left(6-\mathrm{OCH}_{3}\right), 43.0,(\mathrm{C}-8, \mathrm{C}-$ 10)), 42.8 C-2), $41.6(\mathrm{C}-7), 40.2\left[3^{\prime} \mathrm{N}\left(\mathrm{CH}_{3}\right)_{2}\right], 36.6(\mathrm{C}-4), 35.9\left(\mathrm{CH}_{2}\right), 30.5\left(\mathrm{CH}_{2}\right), 30.3\left(\mathrm{C}-4^{\prime}\right), 22.8\left(8-\mathrm{CH}_{3}\right), 21.2$ $(\mathrm{C}-14), 20.8\left(5^{\prime}-\mathrm{CH}_{3}\right), 20.5\left(6-\mathrm{CH}_{3}\right), 16.3\left(12-\mathrm{CH}_{3}\right), 15.6\left(2-\mathrm{CH}_{3}\right), 10.8\left(14-\mathrm{CH}_{3}\right), 10.3\left(10-\mathrm{CH}_{3}\right), 9.4\left(4-\mathrm{CH}_{3}\right)$.

175.2 (C-1, C-9), 171.1 (3-OCO), 133.5, 129.4, 128.5127 .2 (Ph), 102.7 (C-1'), 81.5 (C-5), 78.4 (C-6), 77.6 (C-3), $77.4(\mathrm{C}-13), 74.9(\mathrm{C}-12), 70.7(\mathrm{C}-11), 70.2\left(\mathrm{C}-2^{\prime}\right), 68.7\left(\mathrm{C}-5^{\prime}\right), 66.5\left(\mathrm{C}-3^{\prime}\right), 51.0\left(6-\mathrm{OCH}_{3}\right), 43.0,(\mathrm{C}-2), 42.9 \mathrm{C}-8$, $\left.\mathrm{C}-10), 41.7(\mathrm{C}-7), 41.5 \mathrm{CH}_{2}\right), 40.1$ [3' $\left.\mathrm{N}\left(\mathrm{CH}_{3}\right)_{2}\right], 36.9(\mathrm{C}-4), 29.8\left(\mathrm{C}-4^{\prime}\right), 22.8\left(8-\mathrm{CH}_{3}\right), 21.2(\mathrm{C}-14), 20.8\left(5^{\prime}-\mathrm{CH}_{3}\right)$, $20.6\left(6-\mathrm{CH}_{3}\right), 16.3\left(12-\mathrm{CH}_{3}\right), 15.5\left(2-\mathrm{CH}_{3}\right), 10.8\left(14-\mathrm{CH}_{3}\right), 10.3\left(10-\mathrm{CH}_{3}\right), 9.4\left(4-\mathrm{CH}_{3}\right)$.

All spectra were taken in $\mathrm{CDCl}_{3}$ at $125 \mathrm{MHz}$ and chemical shifts are reported in ppm relative to TMS.

On the basis of previous reports [10] that the introductions of cyclic carbonate to the 11,12-position of macrolide derivatives enhanced the antibacterial activity, the 11,12-cyclic carbonate analogues were synthesized by known method $[11,12]$. Key intermediates for compounds 11 and 12, 3-O-decladinosyl-carbonates 9 and 10, were obtained either from 1a and $\mathbf{2 a}$, with hydrolytic cleavage of cladinose in the final step, or from 3-O-decladinosyl precursors $\mathbf{3 a}$ and $\mathbf{4 a}$, which reacted with ethylene carbonate in the final step. Oxidation of $\mathbf{9}$ and $\mathbf{1 0}$ under condition described above for 5 and $\mathbf{6}$ provided 3-keto11,12-carbonates $\mathbf{1 1}$ and 12, while acylation afforded 3-Oacyl-11,12-carbonates 13 15, Fig. 3 .

MS and NMR spectra confirmed the structures of all compounds. For example, the ${ }^{13} \mathrm{C}$ NMR spectra of $3-$ hydroxy and 3-keto compounds revealed the shift of the $\mathrm{C}$ 3 signal in 3-hydroxy compounds $\mathbf{3 a} \sim \mathbf{c}, \mathbf{4 a} \sim \mathbf{c}, \mathbf{9}$ and $\mathbf{1 0}$ from around $78 \mathrm{ppm}$ to the carbonyl signal around $206 \mathrm{ppm}$ in compounds $\mathbf{5 a} \sim \mathbf{c}, \mathbf{6 a} \sim \mathbf{c}, \mathbf{1 1}$ and 12. The long-range coupling of $\mathrm{H}-2$ and $\mathrm{H}-4$ to this carbonyl group provided evidence that a new-formed carbonyl group was at C-3 position of the azalide ring.

Similar, acylation of 3-hydroxy group was indicated by appearance of new ${ }^{13} \mathrm{C}$ carboxylic signal around $170 \mathrm{ppm}$. The connectivity between this signal and H-3 in HMBC spectrum confirmed the position of acyl group in compounds 13 $\mathbf{3 2}$.

The ${ }^{13} \mathrm{C}$ NMR data for 3-keto $\mathbf{5 a} \sim \mathbf{c}, \mathbf{6 a} \sim \mathbf{c}$ and 3-O-acyl8a-lactam derivatives $\mathbf{1 6} \sim \mathbf{2 8}$ are summarized in Tables 1,2 .

\section{Results and Discussion}

In vitro antibacterial activity of all compounds was determined against the panel of diverse bacterial stains, covering most important Gram-positive (i.e. Streptococcus pneumoniae, S. pyogenes) and Gram-negative (i.e. Haemophilus influenzae, Moraxella catarrhalis) respiratory tract pathogens and different mechanisms of macrolide 
Table $2{ }^{13} \mathrm{C}$ NMR data for 3-keto derivatives of 9a- and 8a-lactams

\begin{tabular}{|c|c|}
\hline Compound & $\delta$ \\
\hline $5 a$ & $\begin{array}{l}206.8(\mathrm{C}-3), 177.3(\mathrm{C}-1), 173.8(\mathrm{C}-9), 102.6\left(\mathrm{C}-1^{\prime}\right), 79.3(\mathrm{C}-13), 78.4(\mathrm{C}-6), 74.4(\mathrm{C}-5), 73.9(\mathrm{C}-12), 73.1(\mathrm{C}-11), 70.0\left(\mathrm{C}-2^{\prime}\right), \\
69.1\left(\mathrm{C}-5^{\prime}\right), 65.5\left(\mathrm{C}-3^{\prime}\right), 50.1\left(6-\mathrm{OCH}_{3}\right), 49.0(\mathrm{C}-2), 46.2(\mathrm{C}-4), 45.3(\mathrm{C}-10), 40.3(\mathrm{C}-7), 40.0\left[3^{\prime}-\mathrm{N}\left(\mathrm{CH}_{3}\right)_{2}\right], 34.6(\mathrm{C}-8), 28.3 \\
\left(\mathrm{C}^{\prime} 4^{\prime}\right), 20.7(\mathrm{C}-14), 10.7\left(15-\mathrm{CH}_{3}\right) .\end{array}$ \\
\hline $5 b$ & $\begin{array}{l}206.1(\mathrm{C}-3), 177.0(\mathrm{C}-9), 174.8(\mathrm{C}-1), 102.5\left(\mathrm{C}-1^{\prime}\right), 80.3(\mathrm{C}-13), 79.3(\mathrm{C}-6), 74.2(\mathrm{C}-11, \mathrm{C}-5), 70.2\left(\mathrm{C}-2^{\prime}\right), 69.4\left(\mathrm{C}-5^{\prime}\right), 65.8 \\
\left(\mathrm{C}-3^{\prime}\right), 57.8\left(6-\mathrm{OCH}_{2} \mathrm{CH}_{3}\right), 49.1(\mathrm{C}-2), 46.0(\mathrm{C}-4), 45.8(\mathrm{C}-10), 41.4(\mathrm{C}-7), 40.3\left[3^{\prime}-\mathrm{N}\left(\mathrm{CH}_{3}\right)_{2}\right), 33.6(\mathrm{C}-8), 28.6\left(\mathrm{C}-4^{\prime}\right), 21.2(\mathrm{C}- \\
\text { 14), } 16.3\left(6-\mathrm{OCH}_{2} \mathrm{CH}_{3}\right) 11.1\left(14-\mathrm{CH}_{3}\right) .\end{array}$ \\
\hline $5 c$ & $\begin{array}{l}206.7(\mathrm{C}-3), 176.9(\mathrm{C}-9), 174.1(\mathrm{C}-1), 136.1\left(6-\mathrm{OCH}_{2} \underline{\mathrm{CH}}=\mathrm{CH}_{2}\right), 117.2\left(6-\mathrm{OCH}_{2} \mathrm{CH}=\underline{\mathrm{CH}}_{2}\right), 101.8\left(\mathrm{C}-1^{\prime}\right), 79.8(\mathrm{C}-13), 79.5 \\
(\mathrm{C}-6), 74.9(\mathrm{C}-5), 74.2(\mathrm{C}-12), 73.4(\mathrm{C}-11), 70.0\left(\mathrm{C}-2^{\prime}\right), 68.7\left(\mathrm{C}-5^{\prime}\right), 66.0\left(\mathrm{C}-3^{\prime}\right), 63.9\left(6-\mathrm{CH}_{2} \mathrm{CH}=\mathrm{CH}_{2}\right), 49.2(\mathrm{C}-2), 46.0(\mathrm{C}- \\
\text { 4), } 44.9(\mathrm{C}-10), 41.1(\mathrm{C}-7), 40.5\left[3^{\prime}-\mathrm{N}\left(\mathrm{CH}_{3}\right)_{2}\right], 34.2(\mathrm{C}-8), 30.7\left(\mathrm{C}-4^{\prime}\right), 20.8(\mathrm{C}-14), 11.1\left(14-\mathrm{CH}_{3}\right) .\end{array}$ \\
\hline $6 a$ & $\begin{array}{l}206.2\left((\mathrm{C}-3), 170.0(\mathrm{C}-9), 174.6(\mathrm{C}-1), 103.1\left(\mathrm{C}-1^{\prime}\right), 78.2(\mathrm{C}-6), 77.9(\mathrm{C}-5), 77.5(\mathrm{C}-13), 74.1(\mathrm{C}-12), 70.6(\mathrm{C}-11), 70.0(\mathrm{C}-\right. \\
\left.2^{\prime}\right), 69.1\left(\mathrm{C}-5^{\prime}\right), 65.5\left(\mathrm{C}-3^{\prime}\right), 50.5\left(6-\mathrm{OCH}_{3}\right), 50.4(\mathrm{C}-2), 47.6(\mathrm{C}-4), 42.2(\mathrm{C}-10), 42.1(\mathrm{C}-7), 41.6(\mathrm{C}-8), 39.9\left[3^{\prime}-\mathrm{N}\left(\mathrm{CH}_{3}\right)_{2}\right] \\
28.0\left(\mathrm{C}-4^{\prime}\right), 22.8\left(8-\mathrm{CH}_{3}\right), 21.2(\mathrm{C}-14), 10.5\left(15-\mathrm{CH}_{3}\right) .\end{array}$ \\
\hline $6 b$ & $\begin{array}{l}205.9(\mathrm{C}-3), 175.5(\mathrm{C}-9), 170.9(\mathrm{C}-1), 103.8\left(\mathrm{C}-1^{\prime}\right), 81.4(\mathrm{C}-5), 78.4(\mathrm{C}-13), 78.3(\mathrm{C}-6), 70.4\left(\mathrm{C}-2^{\prime}\right), 71.3(\mathrm{C}-11), 69.7\left(\mathrm{C}-5^{\prime}\right), \\
65.9\left(\mathrm{C}-3^{\prime}\right), 58.3\left(6-\mathrm{O}^{\mathrm{CH}}{ }_{2} \mathrm{CH}_{3}\right), 50.3(\mathrm{C}-2), 47.4(\mathrm{C}-4), 42.6(\mathrm{C}-10), 41.9(\mathrm{C}-7), 40.4\left[3^{\prime}-\mathrm{N}_{(}\left(\mathrm{CH}_{3}\right)_{2}\right], 28.6\left(\mathrm{C}-4^{\prime}\right), 21.5(\mathrm{C}-14), \\
15.6\left(6-\mathrm{OCH}_{2} \underline{\mathrm{CH}}_{3}\right) 10.8\left(14-\mathrm{CH}_{3}\right) .\end{array}$ \\
\hline $6 c$ & $\begin{array}{l}206.2(\mathrm{C}-3), 174.4(\mathrm{C}-9), 170.5(\mathrm{C}-1), 136.8\left(6-\mathrm{OCH}_{2} \mathrm{CH}=\mathrm{CH}_{2}\right), 115.6\left(6-\mathrm{OCH}_{2} \mathrm{CH}=\mathrm{CH}_{2}\right), 102.6\left(\mathrm{C}-1^{\prime}\right), 78.8(\mathrm{C}-6), 77.8(\mathrm{C}- \\
\text { 13), } 77.6(\mathrm{C}-5), 74.3(\mathrm{C}-12), 70.7(\mathrm{C}-11), 69.9\left(\mathrm{C}-2^{\prime}\right), 69.0\left(\mathrm{C}-5^{\prime}\right), 65.6\left(\mathrm{C}-3^{\prime}\right), 64.0\left(6-\mathrm{O}^{\mathrm{C}} \mathrm{CH}_{2} \mathrm{CH}=\mathrm{CH}_{2}\right), 49.9(\mathrm{C}-2), 46.9(\mathrm{C}- \\
\text { 4), } 42.5(\mathrm{C}-10), 42.2(\mathrm{C}-8), 41.9(\mathrm{C}-7), 40.0\left[3^{\prime}-\mathrm{N}\left(\mathrm{CH}_{3}\right)_{2}\right], 28.6\left(\mathrm{C}-4^{\prime}\right), 21.2(\mathrm{C}-14), 10.5\left(14-\mathrm{CH}_{3}\right) .\end{array}$ \\
\hline
\end{tabular}

All spectra were taken in $\mathrm{CDCl}_{3}$ at $125 \mathrm{MHz}$ and chemical shifts are reported in ppm relative to TMS.

resistance. Efflux mediated resistance gives rise to $\mathrm{M}$ phenotype and is characterized by expression of genes encoding efflux pumps, such as mef in streptococci and msr in staphylococci, that actively extrude macrolide antibiotics from bacterial cells. MLSb phenotype occurs due to expression of erm genes that encode ribosomal methyltransferases, a family of enzymes that specifically methylate ribosomal RNA and therefore prevent binding of macrolide, lincosamide and streptogramin B group of antibiotics.

In all in vitro experiments we used azithromycin as reference compound to novel derivatives, being a "golden standard" in macrolide therapy, due to its superior stability, pharmacokinetic and safety properties over erythromycin A.

\section{In Vitro Evaluation}

The activities are reported in Tables $3 \sim 5$ as minimum inhibitory concentrations (MIC). First we studied a variety of 3-O-acyl 8-a-lactams (compounds 16 28) and their activity is given in Table 3 . To probe the effect of the phenyl group on antibacterial activity we examined unsubstituted (28), 4-nitro substituted (24) and 4-methoxy substituted (26) phenyl derivatives. Compound 24, with electron withdrawing 4-nitro group, demonstrated the best antibacterial activity compared to unsubstituted phenyl ring, or phenyl ring substituted with electron-donating 4-methoxy group, with significant improvement over azithromycin against macrolide resistant strains (i.e. $2 \mu \mathrm{g} / \mathrm{ml} v s .>64$ against MLSb $S$. aureus, $=0.013 \mu \mathrm{g} / \mathrm{ml} v s$. $4 \mu \mathrm{g} / \mathrm{ml}$ against $\mathrm{M} S$. pneumoniae, respectively).

Further we examined the effect of the chain length between macrolide skeleton and aryl ring, by introducing C1 C3 linkers (28, 27 and 16, respectively). Linker elongation decreased the antibacterial activity and the effect was most pronounced against $S$. aureus strains. Insertion of sulphur into the linker (19) did not influence activity substantially, while the presence of nitrogen atom in $\mathbf{1 7}$ resulted with diminished activity, especially against macrolide resistant strains.

Introduction of pyridyl ring (22 and 23), compared to phenyl ring (28), enhanced activity against macrolide sensitive strains, but decreases activity against macrolide resistant pathogens. The presence of naphthyl ring in $\mathbf{2 0}$ resulted in similar antimicrobial spectrum as $\mathbf{2 8}$, but increased activity against susceptible $S$. pyogenes.

As 4-nitrophenylacetyl derivative $\mathbf{2 4}$ was the most active 3-O-acyl derivative, we continued further chemical modification focusing on macrolide skeleton while maintaining this group at $\mathrm{C}-3$ position. Consequently, $8 \mathrm{a}$ 
Table 3 Antibacterial activity of 3-O-decladinosyl-3-O-acyl-6-O-methyl-8a-aza-8a-homoerythromycins

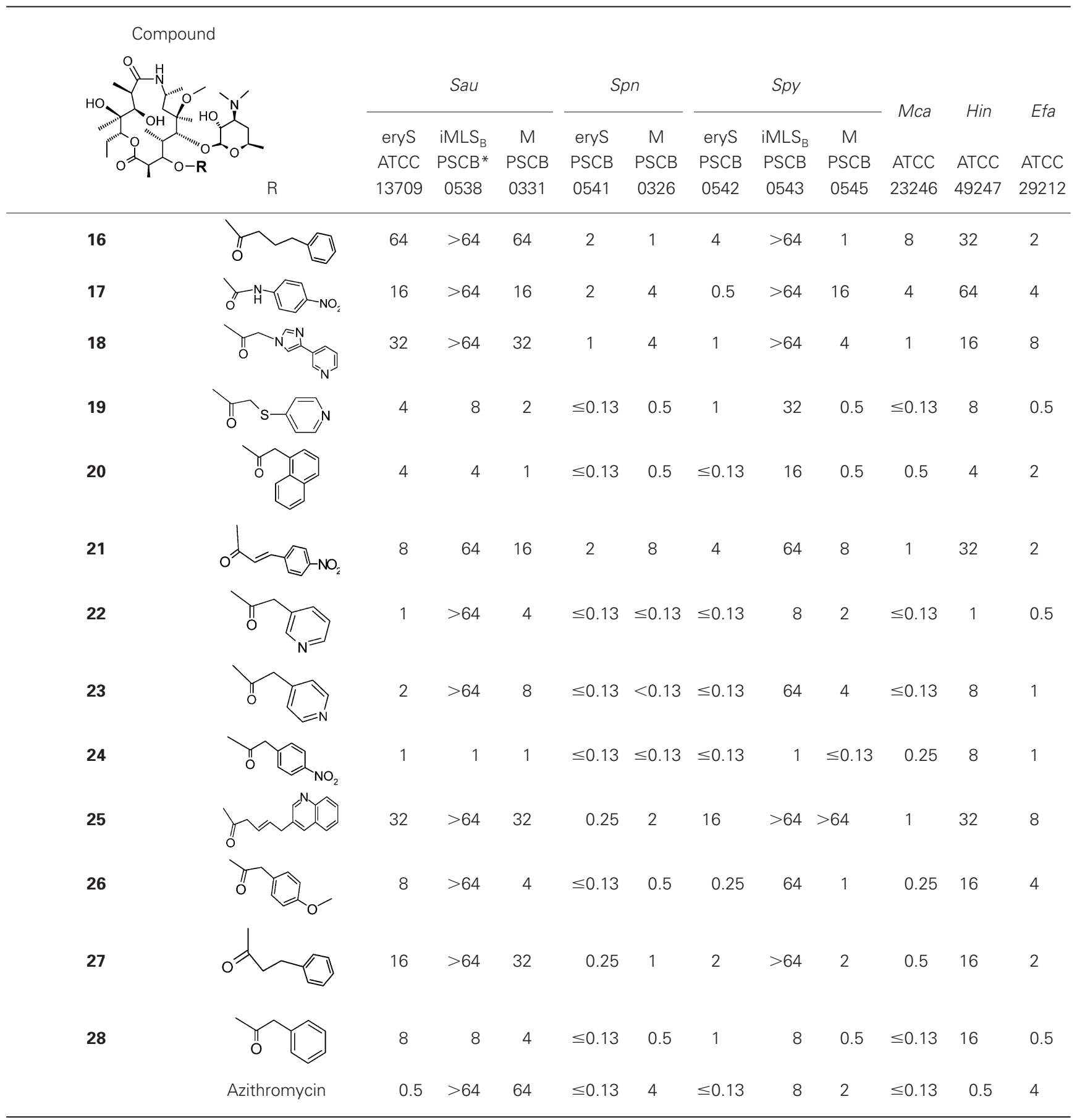

Sau, Staphylococcus aures; Spn, Streptococcus pneumoniae; Spy, Streptococcus pyogenes; Mca, Moraxella catarrhalis; Hin, Haemophilus influenzae; Efa, Enterococcus faecalis.

* Bacterial strains are clinical isolates from various clinical institutions, stored and characterised in GlaxoSmithKline Research Centre Zagreb (formerly Pliva Research Institute) Microbial strain collection.

and 9a-lactams, with or without 11,12-cyclic carbonate, having 6-OH or 6-O-C $\mathrm{C}_{1 \sim 2}$ alkyl group were prepared, Table 4. All 9a-lactams $(\mathbf{2 9}, \mathbf{1 3}, \mathbf{3 0})$ showed inferior activity compared to their 8a-lactam counterparts $(\mathbf{2 4}, \mathbf{1 4}, \mathbf{3 1})$. Compared to the parent 11,12-diol acylides $\mathbf{2 4}$ and $\mathbf{2 9}$, their 11,12-carbonate derivatives $\mathbf{1 4}$ and $\mathbf{1 3}$, respectively, exhibit reduced activity against both macrolide sensitive and efflux resistant Streptococci strains. This result contrasted with the results for the 14-membered macrolides in which introduction of 11,12-cyclic carbonate group led to 
Table 4 Antibacterial activities of 3-O-(4-nitrophenyl)acetyl-8a- and 9a-lactams

\begin{tabular}{|c|c|c|c|c|c|c|c|c|c|c|c|c|}
\hline & \multirow{2}{*}{ Compound } & \multicolumn{3}{|c|}{ Sau } & \multicolumn{2}{|c|}{ Spn } & \multicolumn{3}{|c|}{ Spy } & \multirow{2}{*}{ Mca } & \multirow{2}{*}{ Hin } & \multirow{2}{*}{ Efa } \\
\hline & & erys & $\mathrm{iMLS}_{\mathrm{B}}$ & $\mathrm{M}$ & erys & M & erys & $\mathrm{iMLS}_{\mathrm{B}}$ & $M$ & & & \\
\hline 32 & & 2 & $>128$ & 1 & $\leq 0.25$ & $\leq 0.25$ & $\leq 0.25$ & 16 & $\leq 0.25$ & $\leq 1$ & 2 & $\leq 1$ \\
\hline 24 & & 1 & 1 & 1 & $\leq 0.13$ & $\leq 0.13$ & $\leq 0.13$ & 1 & $\leq 0.13$ & 0.25 & 8 & 1 \\
\hline 29 & & 8 & 8 & 16 & $\leq 0.13$ & $\leq 0.13$ & $\leq 0.13$ & 1 & 0.25 & 0.25 & 16 & 4 \\
\hline 14 & & 4 & 4 & 4 & $\leq 0.13$ & $\leq 0.13$ & $\leq 0.13$ & 1 & 0.5 & 1 & 8 & 1 \\
\hline 13 & & $>64$ & $>64$ & $>64$ & 0.5 & 1 & 1 & $>64$ & 4 & 4 & 32 & 32 \\
\hline 31 & & 4 & $>64$ & 4 & $\leq 0.13$ & $\leq 0.13$ & $\leq 0.13$ & $>64$ & $\leq 0.13$ & $\leq 0.13$ & 4 & 8 \\
\hline 30 & & $>64$ & $>64$ & $>64$ & 8 & 16 & 8 & $>64$ & 8 & 2 & $>64$ & 64 \\
\hline & Azithromy & 0.5 & $>64$ & 64 & $=0.13$ & 4 & $=0.13$ & 8 & 2 & $=0.13$ & 0.5 & 4 \\
\hline
\end{tabular}

Sau, Staphylococcus aures; Spn, Streptococcus pneumoniae; Spy, Streptococcus pyogenes; Mca, Moraxella catarrhalis; Hin, Haemophilus influenzae; Efa, Enterococcus faecalis.

improved activity $[10,13]$. Regarding alkylation at the 6-hydroxyl group, the best activity was shown by the compound with 6-O-methyl group (24). Overall, 6-Omethyl-3-O-acyl-8a-lactam (24) was found to be the most effective against all the pathogens tested.

Furthermore, we examined compounds having 3-keto instead of 3-O-acyl group, with varying macrolide skeleton, Table 5, and found that SAR is similar to 3-Oacyl series. The 6-O-methyl-8a-lactam (6a), which is a 3keto counterpart of $\mathbf{2 4}$, displayed the best antibacterial activity.

Based on the above results of in vitro antibacterial activity, compounds $\mathbf{6 a}$ and $\mathbf{2 4}$ were selected for further pharmacokinetic and in vivo efficacy evaluation. 
Table 5 Antibacterial activities of 3-keto-8a- and 9a-lactams

\begin{tabular}{|c|c|c|c|c|c|c|c|c|c|c|c|c|}
\hline & \multirow{2}{*}{ Compound } & \multicolumn{3}{|c|}{ Sau } & \multicolumn{2}{|c|}{ Span } & \multicolumn{3}{|c|}{ Spy } & \multirow{2}{*}{ Mca } & \multirow{2}{*}{ Hin } & \multirow{2}{*}{$E f a$} \\
\hline & & erys & $\mathrm{iMLS}_{\mathrm{B}}$ & M & erys & M & erys & $\mathrm{iMLS}_{\mathrm{B}}$ & M & & & \\
\hline $6 a$ & & 1 & 4 & 2 & $=0.13$ & 2 & 0.25 & 4 & 4 & $=0.13$ & 2 & 1 \\
\hline $5 a$ & & $>64$ & $>64$ & $>64$ & 64 & $>64$ & $>64$ & $>64$ & $>64$ & 4 & $>64$ & 64 \\
\hline 12 & & 16 & $>64$ & 32 & 1 & 4 & 4 & $>64$ & 8 & $\leq 0.13$ & 32 & 8 \\
\hline 11 & & $>64$ & $>64$ & $>64$ & 8 & 32 & $>64$ & $>64$ & $>64$ & 1 & $>64$ & $>64$ \\
\hline $6 b$ & & 8 & $>64$ & 8 & 0.5 & 4 & 1 & $>64$ & 2 & 0.25 & 8 & 1 \\
\hline $5 b$ & & $>64$ & $>64$ & $>64$ & $>64$ & $>64$ & $>64$ & $>64$ & $>64$ & 4 & $>64$ & $>64$ \\
\hline $6 c$ & & 8 & $>64$ & 16 & 2 & 4 & 2 & $>64$ & 8 & $=0.13$ & 16 & 4 \\
\hline $5 c$ & & $>64$ & $>64$ & $>64$ & $>64$ & $>64$ & $>64$ & $>64$ & $>64$ & 16 & $>64$ & $>64$ \\
\hline & Azithromycin & 0.5 & $>64$ & 64 & $=0.13$ & 4 & $=0.13$ & 8 & 2 & $=0.13$ & 0.5 & 4 \\
\hline
\end{tabular}

Sau, Staphylococcus aures; Spn, Streptococcus pneumoniae; Spy, Streptococcus pyogenes; Mca, Moraxella catarrhalis; Hin, Haemophilus influenzae; Efa, Enterococcus faecalis.

\section{In Vivo Evaluation}

Pharmacokinetic parameters in mice were determined in plasma and different tissues (liver, kidney, brain, spleen and lungs) for both selected derivatives and are given in Table 6.

The 3-keto compound 6a was very well and rapidly absorbed after oral administration in dose of $100 \mathrm{mg} / \mathrm{kg}$. It achieved peak concentration 30 minutes after administration and showed high tissue accumulation with $\mathrm{AUC}_{(0 \sim 4)}$ levels relative to plasma $\mathrm{AUC}_{(0 \sim 4)}\left(\mathrm{AUC}_{\mathrm{rel}}\right)$ values ranging from 5.7 to 34.6. The only exception to this was brain level with $\mathrm{AUC}_{\mathrm{rel}}$ of 0.31 . This is in accordance with behaviour of macrolides in general, as they are known to penetrate into cerebrospinal fluid very poorly [14]. High accumulation principally in liver tissue could be attributed to the first pass effect after oral administration, as all the blood from gut circulates through liver before going towards heart and other organs. Compound $\mathbf{6 a}$ has relatively short half-life around 2 hours, but its $t_{1 / 2}$ in plasma is prolonged (more than 5 hours), which might 
Table 6 Oral pharmacokinetic parameters of compounds $\mathbf{6 a}$ and $\mathbf{2 4}$ in mice

a) Compound $\mathbf{6 a}$ following a single dose of $100 \mathrm{mg} / \mathrm{kg}$

\begin{tabular}{|c|c|c|c|c|c|c|c|}
\hline Tissue & $C_{\max }(\mu \mathrm{g} / \mathrm{g})$ & $\mathrm{DNC}_{\max }(\mu \mathrm{g} / \mathrm{g})$ & $t_{\max }(h)$ & $\begin{array}{l}A \cup C_{(0 \sim 4)} \\
\left(h^{*} \mu g / g\right)\end{array}$ & $\begin{array}{c}\operatorname{DNAUC}_{(0 \sim 4)} \\
\left(h^{*} \mu \mathrm{g} / \mathrm{g}\right)\end{array}$ & $A \cup C_{r e l}$ & $t_{1 / 2}(h)$ \\
\hline Liver & 987.57 & 9.876 & 0.5 & 798.78 & 7.988 & 34.61 & 1.72 \\
\hline Kidney & 148.89 & 1.489 & 0.5 & 149.99 & 1.500 & 6.49 & 2.57 \\
\hline Brain & 5.26 & 0.053 & 0.5 & 7.16 & 0.072 & 0.31 & n.d. \\
\hline Spleen & 218.66 & 2.187 & 0.5 & 223.43 & 2.234 & 9.68 & 2.16 \\
\hline Lungs & 165.20 & 1.652 & 0.5 & 131.60 & 1.316 & 5.70 & 1.66 \\
\hline Plasma & 12.45 & 0.125 & 0.5 & 23.08 & 0.231 & 1 & 5.29 \\
\hline
\end{tabular}

b) Compound $\mathbf{2 4}$ following a single dose of $50 \mathrm{mg} / \mathrm{kg}$

\begin{tabular}{lccccccc}
\hline Tissue & $C_{\max }(\mu \mathrm{g} / \mathrm{g})$ & $\mathrm{DNC}_{\max }(\mu \mathrm{g} / \mathrm{g})$ & $\mathrm{t}_{\max }(\mathrm{h})$ & $\begin{array}{c}\mathrm{AUC}_{(0 \sim 4)} \\
\left(\mathrm{h}^{*} \mu \mathrm{g} / \mathrm{g}\right)\end{array}$ & $\begin{array}{c}\mathrm{DNAUC}_{(0 \sim 4)} \\
\left(\mathrm{h}^{*} \mu \mathrm{g} / \mathrm{g}\right)\end{array}$ & $\mathrm{AUC}_{\mathrm{rel}}$ \\
\hline Liver & 19.567 & 0.391 & 0.75 & 19.451 & 0.389 & 2.509 & 0.60 \\
Kidney & 16.04 & 0.321 & 0.75 & 10.759 & 0.215 & 1.390 & 0.62 \\
Brain & 1.794 & 0.036 & 0.75 & 2.201 & 0.044 & 0.284 & $3 . \mathrm{d}$ \\
Spleen & 24.933 & 0.499 & 0.75 & 24.016 & 0.480 & 3.103 & 2.39 \\
Lungs & 22.696 & 0.454 & 0.75 & 28.228 & 0.565 & 3.647 & 1.04 \\
Plasma & 4.83 & 0.097 & 0.75 & 7.738 & 0.155 & 1.20 \\
\hline
\end{tabular}

n.d.: not determined. $D N C_{\max }$ DNAUC: dose-normalized $C_{\max }$ and $A \cup C$, respectively. $A \cup C_{\text {rel }}$ : $A \cup C_{\text {tissue }} / A \cup C_{\text {plasma. }}$.

Table $\mathbf{7}$ In vivo efficacy of compounds $\mathbf{6 a}$ and $\mathbf{2 4}$ in comparison with azithromycin against susceptible and inducible-resistant Staphylococcus aureus

\begin{tabular}{ccccc}
\hline Microorganism & Compound & $\mathrm{ED}_{50}(\mathrm{mg} / \mathrm{kg})$ & $95 \%$ Confidence interval & MIC $(\mu \mathrm{g} / \mathrm{ml})$ \\
\hline \multirow{2}{*}{ S. aureus ery-S ATCC 29213 } & $\mathbf{6 a}$ & 48.6 & $33.8 \sim 71.34$ & 1 \\
& $\mathbf{2 4}$ & 29.7 & $12.40 \sim 70.97$ & 2 \\
& Azithromycin & 17.6 & $10.57 \sim 29.17$ & 0.5 \\
S. aureus iMLS ${ }_{\mathrm{B}}$ PSCB 0009 & $\mathbf{6 a}$ & 61.7 & $32.99 \sim 115.36$ & 2 \\
& $\mathbf{2 4}$ & 74.7 & $57.21 \sim 97.52$ & 4 \\
\hline
\end{tabular}

indicate high plasma protein binding. Due to low concentrations, $\mathrm{t}_{1 / 2}$ for brain tissue could not be determined.

The 3-O-acyl compound $\mathbf{2 4}$ was given orally at $50 \mathrm{mg} / \mathrm{kg}$. It was well absorbed, but displayed moderate and more even tissue distribution than 6a, with $\mathrm{AUC}_{\text {rel }}$ ranging from 1.4 to 3.6 , with the exception of brain tissue where $\mathrm{AUC}_{\text {rel }}$ was 0.28. Peak concentrations were reached 45 minutes after administration. Half-life was short, approximately one hour, with the exception of spleen, where it was prolonged to 2.4 hours.
Overall, both derivatives were well absorbed after p.o. administration in mice, had high peak concentrations, pronounced tissue accumulation and relatively short halflife. The 3-keto compound 6a was better absorbed and achieved significantly higher levels than the 3-O-acyl compound $\mathbf{2 4}$ in all organs examined, most markedly in liver where $\mathrm{DNAUC}_{(0 \sim 4)}$ was 20 times higher for $\mathbf{6 a}$ than for 24, and kidney, where 6a $\operatorname{DNAUC}_{(0 \sim 4)}$ was 7 times higher.

The in vivo efficacy of $\mathbf{6 a}, \mathbf{2 4}$ and azithromycin was 
assessed in lethal septicaemia model in mice, using erythromycin susceptible and $\mathrm{iMLS}_{\mathrm{b}}$ resistant strains of Staphylococcus aureus. Mice were infected by single i.v. administration of bacterial suspension and compounds were dosed orally every 12 hours for three days, starting 30 minutes post infection. The efficacy of each compound is reported as the effective drug dosage $\left(\mathrm{ED}_{50}\right)$ that resulted in $50 \%$ survival rate, Table 7. Compounds $\mathbf{6 a}$ and $\mathbf{2 4}$ where effective against ery-S $S$. aureus strains, but less than azithromycin, which could be correlated to corresponding in vitro activities, as well as differences in plasma half-lives (AZM $t_{1 / 2}$ being $>12$ hours [15]). When tested against $\mathrm{iMLS}_{\mathrm{b}}$ resistant $S$. aureus strain, $\mathbf{6 a}$ and $\mathbf{2 4}$ were four times more effective than azithromycin.

\section{Conclusion}

In summary, we have identified a combination of structural factors that contribute to enhancement of antibacterial activity for novel 3-keto- and 3-O-acyl-azalides. These factors are 3-keto group or 3-O-acetyl group having the phenyl unit. In particular, phenyl unit bearing electronwithdrawing $p$-nitro group enhanced activity. Introduction of 11,12-cyclic carbonate substituent decreases activity of all tested compounds, as well as elongation of alkyl chain at 6-position of the lactam ring. Derivatives of 8a-lactam showed superior activity as compared to $9 \mathrm{a}$-analogues.

The encouraging in vivo results for $\mathbf{6 a}$ and $\mathbf{2 4}$ warrant further investigation to overcome $\mathrm{MLS}_{\mathrm{B}}$-resistant pathogens and to develop potential next-generation azalides.

\section{Experimental}

\section{General}

NMR spectra were recorded on a Bruker Avance DRX500 or Bruker Avance DPX300 spectrometer in $\mathrm{CDCl}_{3}$ and chemical shifts are reported in ppm using TMS as an internal standard. Mass spectra were obtained on a Waters Micromass ZQ mass spectrometer for $\mathrm{ES}^{+}$-MS. Silica gel chromatography was performed on Merck Kieselgel 60 and Merck TLC $60 \mathrm{~F}_{254}$, respectively.

In general, organic layer was dried with anhydrous $\mathrm{Na}_{2} \mathrm{SO}_{4}$ or $\mathrm{K}_{2} \mathrm{CO}_{3}$, evaporation and concentration were carried out under reduced pressure below $40^{\circ} \mathrm{C}$, unless otherwise noted.

6-O-Ethyl- and 6-O-allylerythromycin 9-oxime derivatives were prepared from erythromycin $9(E)$-oxime [9] according to the published procedure [8] which include protection, alkylation, deprotection and separation of obtained $9(E)$ - and $9(Z)$-oxime isomers. $2^{\prime}$-O-Acetyl-protected derivatives were prepared by the known procedure $[3,16]$.

\section{Antibacterial Activity in Vitro}

Strains were cultured on MH agar (Merck, Germany) except strains belonging to genus Streptococcus and Haemophilus, which were cultured on blood agar plates (Biomerioux, France) and chocolate agar plates (Biomerioux, France), respectively. Minimum inhibitory concentrations (MICs) were determined by the microtitre liquid dilution method as described by NCCLS [17] except that for Streptococcus medium, blood was substituted with $5 \%$ horse serum.

\section{Pharmacokinetics in Mice}

Experiments were carried out on male Balb/c mice (Charles River, Germany), weighing 20 25 g, divided into groups, 6 mice each. Substances were administered p.o. to fasted mice as suspension in $0.5 \%$ carboxy - methylcellulose $(\mathrm{w} / \mathrm{v})$ (SIGMA) saline solution (0.9\%) (PLIVA) at $100 \mathrm{mg} / \mathrm{kg}$ (6a) and $50 \mathrm{mg} / \mathrm{kg}$ (24). Blood and tissue samples (liver, kidney, lung, brain and spleen) were taken at $0.25,0.5,1,2$, 4, 6, 12, 24 and 48 hours after administration of $\mathbf{6 a}$ and at $0.25,0.75,1.5,2,3,4,6,12,24,48$ and 72 hours in case 24. The concentrations of the compounds were measured by microbiological agar diffusion method using Micrococcus luteus as test microorganism.

\section{In Vivo Efficacy}

In vivo efficacy of selected compounds was tested in $S$. aureus lethal septicaemia mouse model using Balb/c mice (Charles River, Germany), weighing 20 25 g, divided into groups consisting of 10 mice each. Strains were grown overnight in MHB (Merck, Germany) at $37^{\circ} \mathrm{C}$. Cells were suspended in fresh medium and the inoculum size (CFU/mouse) was adjusted to $1.0 \times 10^{7}$ for both eryS (ATCC 29213) and iMLS B $_{\mathrm{B}}$ strains (Pliva Strain Collection Bacteria, PSCB 0009). Mice were infected by single i.v. administration. Therapy started 30 minutes after infection and daily p.o. doses were administered in two portions every 12 hours for 3 days. Compounds were dissolved in DMF (Merck, Germany) given as $0.5 \%$ carboxy methylcellulose $(\mathrm{w} / \mathrm{v})$ (SIGMA) saline solution $(0.9 \%)$ (PLIVA) and 3\% with respect to DMF. Survival was measured after 6 days. $\mathrm{ED}_{50}$ values were calculated by inhouse log-probit method.

6-O-Methyl-9a-aza-9a-homoerythromycin A (1a)

6-O-Methylerythromycin A 9(E)-oxime $(4.0 \mathrm{~g}, 0.005 \mathrm{~mol})$ was dissolved in acetone $(130 \mathrm{ml})$ and the solution was cooled to $0 \sim 5^{\circ} \mathrm{C}$. Subsequently, 4-toluenesulfonyl chloride 
$(2.6 \mathrm{~g}, 0.01 \mathrm{~mol})$ in acetone $(40 \mathrm{ml})$ and sodium hydrogen carbonate $(0.83 \mathrm{~g}, 0.01 \mathrm{~mol})$ in water $(130 \mathrm{ml})$ were added dropwise thereto within 1 hour under stirring. After stirring at room temperature for 8 hours, acetone was evaporated and aqueous solution was extracted with $\mathrm{CHCl}_{3}$ by gradient extraction at $\mathrm{pH} 5$ and 9. The combined organic layers at $\mathrm{pH}$ 9 were evaporated to give $\mathbf{1 a}(2.8 \mathrm{~g}, 70 \%)$ as a white solid.

${ }^{13} \mathrm{C} \mathrm{NMR}\left(75 \mathrm{MHz}, \mathrm{CDCl}_{3}\right) \delta 179.5(\mathrm{C}-1), 177.3(\mathrm{C}-9)$, $102.5\left(\mathrm{C}-1^{\prime}\right), 94.9\left(\mathrm{C}-1^{\prime \prime}\right), 79.4$ (C-6), 78.5 (C-5), 77.7 (C4"), 77.7 (C-13), 75.9 (C-3), 73.9 (C-12), 72.6 (C-11), 72.5 $\left(\mathrm{C}-3^{\prime \prime}\right), 70.7\left(\mathrm{C}-2^{\prime}\right), 68.2\left(\mathrm{C}-5^{\prime}\right), 65.3\left(\mathrm{C}-5^{\prime \prime}\right), 65.1\left(\mathrm{C}-3^{\prime}\right)$, $51.0\left(6-\mathrm{OCH}_{3}\right), 49.1\left(3^{\prime \prime}-\mathrm{OCH}_{3}\right), 45.1(\mathrm{C}-10), 44.5(\mathrm{C}-2)$, 41.3 (C-4), 40.0 [3'-N( $\left(\mathrm{CH}_{3}\right)_{2}$ ], 39.6 (C-7), 35.4 (C-8), 34.4 $\left(\mathrm{C}-2^{\prime \prime}\right), 28.8\left(\mathrm{C}-4^{\prime}\right), 21.1\left(5^{\prime}-\mathrm{CH}_{3}\right), 21.0\left(3^{\prime \prime}-\mathrm{CH}_{3}\right), 20.3$ (C-14), $20.2\left(6-\mathrm{CH}_{3}\right), 19.1\left(8-\mathrm{CH}_{3}\right), 18.1\left(5^{\prime \prime}-\mathrm{CH}_{3}\right), 15.9$ $\left(12-\mathrm{CH}_{3}\right), 14.6\left(2-\mathrm{CH}_{3}\right), 13.4\left(10-\mathrm{CH}_{3}\right), 10.7\left(14-\mathrm{CH}_{3}\right), 8.7$ $\left(4-\mathrm{CH}_{3}\right)$.

$\mathrm{ES}^{+}-\mathrm{MS} m / z 763.6(\mathrm{M}+\mathrm{H})^{+}$

6-O-Ethyl-9a-aza-9a-homoerythromycin A (1)

Reaction of 6-O-ethylerythromycin A 9(E)-oxime with 4toluenesulfonyl chloride gave $\mathbf{1 b}$ as a colourless solid in $85 \%$ yield by a similar procedure to $1 \mathbf{a}$.

${ }^{13} \mathrm{C}$ NMR $\left(125 \mathrm{MHz}, \mathrm{CDCl}_{3}\right) \delta 179.3(\mathrm{C}-1), 177.1$ (C-9), $102.1\left(\mathrm{C}-1^{\prime}\right), 96.0\left(\mathrm{C}-1^{\prime \prime}\right), 80.1$ (C-6), 79.0 (C-13), 78.8 (C5), 77.8 (C-3), 77.7 (C-4"), 74.2 (C-12), 73.7 (C-11), 73.0 $\left(\mathrm{C}-3^{\prime \prime}\right), 71.1\left(\mathrm{C}-2^{\prime}\right), 68.4\left(\mathrm{C}-5^{\prime}\right), 65.5\left(\mathrm{C}-3^{\prime}\right), 66.4\left(\mathrm{C}-5^{\prime \prime}\right)$, $58.8\left(6-\mathrm{OCH}_{2} \mathrm{CH}_{3}\right), 49.4\left(3^{\prime \prime}-\mathrm{OCH}_{3}\right), 45.5(\mathrm{C}-10), 44.7(\mathrm{C}-$ 2), 40.4 (C-7), 40.1 (C-4), 34.4 (C-8), 40.5 [3'-N( $\left.\left(\mathrm{CH}_{3}\right)_{2}\right]$, $35.1\left(\mathrm{C}-2^{\prime \prime}\right), 29.3\left(\mathrm{C}-4^{\prime}\right), 21.2\left(6-\mathrm{OCH}_{2} \mathrm{CH}_{3}\right) 20.8(\mathrm{C}-14)$, $11.2\left(14-\mathrm{CH}_{3}\right)$.

$\mathrm{ES}^{+}$-MS $m / z 777.5(\mathrm{M}+\mathrm{H})^{+}$

6-O-Allyl-9a-aza-9a-homoerythromycin A (1c)

The title compound was prepared from 6-Oallylerythromycin A 9(E)-oxime and 4-toluenesulfonyl chloride in $10.7 \%$ yield according to the procedure used to prepare $\mathbf{1 a}$.

${ }^{13} \mathrm{C}$ NMR $\left(125 \mathrm{MHz}, \mathrm{CDCl}_{3}\right) \delta 179.3(\mathrm{C}-1), 177.1(\mathrm{C}-9)$, $136.6\left(6-\mathrm{OCH}_{2} \underline{\mathrm{CH}}=\mathrm{CH}_{2}\right), \quad 118.0 \quad\left(6-\mathrm{OCH}_{2} \mathrm{CH}=\underline{\mathrm{CH}_{2}}\right)$, $102.5\left(\mathrm{C}-1^{\prime}\right), 95.6\left(\mathrm{C}-1^{\prime \prime}\right), 80.6$ (C-6), 78.9 (C-5), 78.4 (C13), 77.9 (C-4"), 77.2 (C-3), 74.3 (C-12), 73.1 (C-11), 72.9 $\left(\mathrm{C}-3^{\prime \prime}\right), 71.1\left(\mathrm{C}-2^{\prime}\right), 68.5\left(\mathrm{C}-5^{\prime}\right), 66.1\left(\mathrm{C}-5^{\prime \prime}\right), 65.5\left(\mathrm{C}-3^{\prime}\right)$, $65.3\left(6-\mathrm{OCH}_{2} \mathrm{CH}=\mathrm{CH}_{2}\right), 49.4\left(3^{\prime \prime}-\mathrm{OCH}_{3}\right), 45.6(\mathrm{C}-10)$, 44.8 (C-2), 41.0 (C-4), 40.2 (C-7), 40.5 [3'- $\left.\mathrm{N}^{\prime}\left(\mathrm{CH}_{3}\right)_{2}\right], 35.2$ (C-8), 35.0 (C-2"), 29.5 (C-4'), 20.8 (C-14), $11.1\left(14-\mathrm{CH}_{3}\right)$.

$\mathrm{ES}^{+}$-MS $m / z 789.8(\mathrm{M}+\mathrm{H})^{+}$

6-O-Methyl-8a-aza-8a-homoerythromycin A (2a)

Reaction of 6-O-methylerythromycin A 9(Z)-oxime with 4toluenesulfonyl chloride gave $\mathbf{2 a}$ as a colourless solid in
$58 \%$ yield by a similar procedure to $1 \mathrm{a}$.

${ }^{13} \mathrm{C}$ NMR $\left(75 \mathrm{MHz}, \mathrm{CDCl}_{3}\right) \delta 177.0(\mathrm{C}-1), 174.3$ (C-9), $102.9\left(\mathrm{C}-1^{\prime}\right), 95.1\left(\mathrm{C}-1^{\prime \prime}\right), 80.1$ (C-5), 78.6 (C-6), 77.9 (C$\left.4^{\prime \prime}\right), 77.2$ (C-3), 76.7 (C-13), 74.0 (C-12), 72.6 (C-3"), 70.4 (C-2'), 70.1 (C-11), 68.7 (C-5'), $65.4\left(\mathrm{C}-3^{\prime}\right), 65.2\left(\mathrm{C}-5^{\prime \prime}\right)$, $51.5\left(6-\mathrm{OCH}_{3}\right), 49.1\left(3^{\prime \prime}-\mathrm{OCH}_{3}\right), 45.4(\mathrm{C}-2), 42.6(\mathrm{C}-7)$, 42.1 (C-4), 41.8 (C-10), 40.6 (C-8), 40.0 [3'-N( $\left.\left.\mathrm{CH}_{3}\right)_{2}\right]$, $34.5\left(\mathrm{C}-2^{\prime \prime}\right), 28.3\left(\mathrm{C}-4^{\prime}\right), 23.5\left(6-\mathrm{CH}_{3}\right), 21.3(\mathrm{C}-14), 21.2$ $\left(12-\mathrm{CH}_{3}\right), 21.1\left(5^{\prime}-\mathrm{CH}_{3}\right), 21.1\left(3^{\prime \prime}-\mathrm{CH}_{3}\right), 17.9\left(5^{\prime \prime}-\mathrm{CH}_{3}\right)$, $15.8\left(8-\mathrm{CH}_{3}\right), 14.8\left(2-\mathrm{CH}_{3}\right), 10.8\left(14-\mathrm{CH}_{3}\right), 9.2\left(10-\mathrm{CH}_{3}\right)$, $9.1\left(4-\mathrm{CH}_{3}\right)$.

$\mathrm{ES}^{+}-\mathrm{MS} m / z 763.6(\mathrm{M}+\mathrm{H})^{+}$

6-O-Ethyl-8a-aza-8a-homoerythromycin A (2b)

Reaction of 6-O-ethylerythromycin A 9(Z)-oxime with 4toluenesulfonyl chloride gave $\mathbf{2 b}$ as a colourless solid in $89 \%$ yield by a similar procedure to $1 \mathbf{1 a}$.

${ }^{13} \mathrm{C}$ NMR (125 MHz, $\left.\mathrm{CDCl}_{3}\right) \delta 175.0(\mathrm{C}-9), 174.1(\mathrm{C}-1)$, $103.3\left(\mathrm{C}-1^{\prime}\right), 97.3\left(\mathrm{C}-1^{\prime \prime}\right), 82.6$ (C-5), 81.9 (C-3), 78.5 (C6), 77.7 (C-4"), 77.0 (C-13), 73.5 (C-12), 72.4 (C-3"), 70.7 (C-11), $70.4\left(\mathrm{C}-2^{\prime}\right), 68.8\left(\mathrm{C}-5^{\prime}\right), 65.2\left(\mathrm{C}-3^{\prime}\right), 65.2\left(\mathrm{C}-5^{\prime \prime}\right)$, $60.0\left(6-\mathrm{OCH}_{2} \mathrm{CH}_{3}\right), 48.9\left(3^{\prime \prime}-\mathrm{OCH}_{3}\right), 45.2(\mathrm{C}-2), 42.0(\mathrm{C}-$ 7), 41.4 (C-8, C-10), 40.2 (C-4), 40.0 [3'-N( $\left.\left(\mathrm{CH}_{3}\right)_{2}\right], 35.2$ $\left(\mathrm{C}-2^{\prime \prime}\right), 28.7\left(\mathrm{C}-4^{\prime}\right), 21.0(\mathrm{C}-14), 10.2\left(14-\mathrm{CH}_{3}\right)$.

$\mathrm{ES}^{+}$-MS $m / z 777.6(\mathrm{M}+\mathrm{H})^{+}$

6-O-Allyl-8a-aza-8a-homoerythromycin A (2c)

The title compound was prepared from 6-Oallylerythromycin A 9(Z)-oxime and 4-toluenesulfonyl chloride in $25 \%$ yield according to the procedure used to prepare 1a.

${ }^{13} \mathrm{C}$ NMR $\left(125 \mathrm{MHz}, \mathrm{CDCl}_{3}\right) \delta 175.8(\mathrm{C}-1), 174.5(\mathrm{C}-9)$, $137.6\left(6-\mathrm{OCH}_{2} \underline{\mathrm{CH}}=\mathrm{CH}_{2}\right), \quad 115.7 \quad\left(6-\mathrm{OCH}_{2} \mathrm{CH}=\underline{\mathrm{CH}}_{2}\right)$, $103.3\left(\mathrm{C}-1^{\prime}\right), 95.6\left(\mathrm{C}-1^{\prime \prime}\right), 81.4(\mathrm{C}-5), 80.2(\mathrm{C}-6), 79.9(\mathrm{C}-$ 3), 78.1 (C-4"), 77.2 (C-13), 74.2 (C-12), 72.9 (C-3"), 70.9 (C-11), $70.8\left(\mathrm{C}-2^{\prime}\right), 69.0\left(\mathrm{C}-5^{\prime}\right), 65.9\left(6-\mathrm{OCH}_{2} \mathrm{CH}=\mathrm{CH}_{2}\right)$, $65.7\left(\mathrm{C}-5^{\prime \prime}\right), 65.6\left(\mathrm{C}-3^{\prime}\right), 49.4\left(3^{\prime \prime}-\mathrm{OCH}_{3}\right), 45.6(\mathrm{C}-2), 42.8$ (C-7), 42.2 (C-10), $41.6(\mathrm{C}-8), 40.4$ [3'-N( $\left.\left(\mathrm{CH}_{3}\right)_{2}\right], 35.4$ (C$\left.2^{\prime \prime}\right), 28.9$ (C-4'), $201.5(\mathrm{C}-14), 10.9\left(14-\mathrm{CH}_{3}\right)$.

$\mathrm{ES}^{+}$-MS $m / z 789.7(\mathrm{M}+\mathrm{H})^{+}$

6-O-Methyl-3-O-decladinosyl-9a-aza-9a-homoerythromycin A (3a)

Compound 1a $(2.8 \mathrm{~g}, 3.7 \mathrm{mmol})$ was dissolved in $0.25 \mathrm{~N}$ $\mathrm{HCl}(100 \mathrm{ml})$ and stirred at room temperature for 24 hours. To the reaction mixture $\mathrm{CH}_{2} \mathrm{Cl}_{2}(50 \mathrm{ml})$ was added, $\mathrm{pH}$ was adjusted to 9.0 by adding conc. $\mathrm{NH}_{4} \mathrm{OH}$ and extracted with $\mathrm{CH}_{2} \mathrm{Cl}_{2}(50 \mathrm{ml} \times 3)$. The combined organic layers were washed with $10 \%$ aq. $\mathrm{NaHCO}_{3}$ and water and evaporated under reduced pressure to give 3a $(2.05 \mathrm{~g}$, $92.3 \%)$. 
${ }^{13} \mathrm{C}$ NMR $\left(75 \mathrm{MHz}, \mathrm{CDCl}_{3}\right) \delta 179.3(\mathrm{C}-1), 176.9(\mathrm{C}-9)$, $106.4\left(\mathrm{C}-1^{\prime}\right), 88.1$ (C-5), 79.1 (C-6), 78.7 (C-13), 78.0 (C3), 73.8 (C-12), 73.9 (C-11), 70.2 (C-2'), 69.7 (C-5'), 65.4 $\left(\mathrm{C}-3^{\prime}\right), 49.9\left(6-\mathrm{OCH}_{3}\right), 45.6(\mathrm{C}-10), 43.9$ (C-2), 40.8 (C-7), 39.9 [3'-N( $\left.\left(\mathrm{CH}_{3}\right)_{2}\right], 35.6$ (C-4), 32.8 (C-8), $27.8\left(\mathrm{C}-4^{\prime}\right), 20.5$ (C-14), $10.7\left(14-\mathrm{CH}_{3}\right)$.

$\mathrm{ES}^{+}-\mathrm{MS} m / z 605.5(\mathrm{M}+\mathrm{H})^{+}$

6-O-Ethyl-3-O-decladinosyl-9a-aza-9a-homoerythromycin $\mathrm{A}(\mathbf{3 b})$

The title compound was prepared from $\mathbf{1 b}$ in $95.2 \%$ yield according to the procedure used to prepare $\mathbf{3 a}$.

${ }^{13} \mathrm{C}$ NMR $\left(125 \mathrm{MHz}, \mathrm{CDCl}_{3}\right) \delta 179.3(\mathrm{C}-1), 177.2(\mathrm{C}-9)$, $107.0\left(\mathrm{C}-1^{\prime}\right), 88.9$ (C-5), 79.7 (C-6), 79.3 (C-13), 78.5 (C3), 74.5 (C-11), 74.3 (C-12), 70.5 (C-2'), 70.2 (C-5'), 65.8 $\left(\mathrm{C}-3^{\prime}\right), 58.1\left(6-\mathrm{OCH}_{2} \mathrm{CH}_{3}\right), 46.0(\mathrm{C}-10), 44.4(\mathrm{C}-2), 41.7$ (C-7), 40.3 [3'-N( $\left.\left(\mathrm{CH}_{3}\right)_{2}\right], 36.0$ (C-4), 32.9 (C-8), 28.0 (C$\left.4^{\prime}\right), 21.0(\mathrm{C}-14), 16.0\left(6-\mathrm{OCH}_{2} \underline{\mathrm{CH}}_{3}\right) 11.1\left(14-\mathrm{CH}_{3}\right)$.

$\mathrm{ES}^{+}-\mathrm{MS} m / z 619.6(\mathrm{M}+\mathrm{H})^{+}$

6-O-Allyl-3-O-decladinosyl-9a-aza-9a-homoerythromycin $\mathrm{A}(\mathbf{3 c})$

The title compound was prepared from $1 \mathbf{c}$ in $32.8 \%$ yield according to the procedure used to prepare $\mathbf{3 a}$.

${ }^{13} \mathrm{C}$ NMR (125 MHz, $\mathrm{CDCl}_{3}$ ) $\delta 179.0(\mathrm{C}-1), 177.0(\mathrm{C}-9)$, $135.2 \quad\left(6-\mathrm{OCH}_{2} \underline{\mathrm{CH}}=\mathrm{CH}_{2}\right), \quad 117.7 \quad\left(6-\mathrm{OCH}_{2} \mathrm{CH}=\underline{\mathrm{CH}}_{2}\right)$, $106.1\left(\mathrm{C}-1^{\prime}\right), 88.8$ (C-5), 80.1 (C-6), 79.0 (C-13), 78.3 (C3), 74.2 (C-11), 70.3 (C-2'), 69.5 (C-5'), $66.1\left(\mathrm{C}-3^{\prime}\right), 64.2$ $\left(6-\mathrm{OCH}_{2} \mathrm{CH}=\mathrm{CH}_{2}\right), 46.1(\mathrm{C}-10), 44.3(\mathrm{C}-2), 41.6(\mathrm{C}-7)$, $40.3\left[3^{\prime}-\mathrm{N}\left(\mathrm{CH}_{3}\right)_{2}\right], 35.9$ (C-4), 33.0 (C-8), 28.9 (C-4'), 20.9 (C-14), $11.1\left(14-\mathrm{CH}_{3}\right)$.

$\mathrm{ES}^{+}$-MS $m / z 631.6(\mathrm{M}+\mathrm{H})^{+}$

6-O-Methyl-3-O-decladinosyl-8a-aza-8a-homoerythromycin A (4a)

The title compound was prepared from $\mathbf{2 a}$ in $82.7 \%$ yield according to the procedure used to prepare $\mathbf{3 a}$.

${ }^{13} \mathrm{C} \mathrm{NMR}\left(125 \mathrm{MHz}, \mathrm{CDCl}_{3}\right) \delta 176.5(\mathrm{C}-1), 174.9(\mathrm{C}-9)$, $106.6\left(\mathrm{C}-1^{\prime}\right), 90.2$ (C-5), 78.9 (C-3), 77.9 (C-6), 76.6 (C13), 75.0 (C-12), 71.0 (C-11), 70.5 (C-2'), 70.1 (C-5'), 65.7 $\left(\mathrm{C}-3^{\prime}\right), 50.5\left(6-\mathrm{OCH}_{3}\right), 44.5(\mathrm{C}-2), 43.2(\mathrm{C}-10), 42.8(\mathrm{C}-8)$, 42.5 (C-7), $40.3\left[3^{\prime}-\mathrm{N}\left(\mathrm{CH}_{3}\right)_{2}\right], 35.9$ (C-4), $28.2\left(\mathrm{C}-4^{\prime}\right), 21.7$ (C-14), $10.9\left(14-\mathrm{CH}_{3}\right)$.

$\mathrm{ES}^{+}-\mathrm{MS} m / z 605.6(\mathrm{M}+\mathrm{H})^{+}$

6-O-Ethyl-3-O-decladinosyl-8a-aza-8a-homoerythromycin $\mathrm{A}(\mathbf{4 b})$

The title compound was prepared from $\mathbf{2 b}$ in $89.3 \%$ yield according to the procedure used to prepare $\mathbf{3 a}$.

${ }^{13} \mathrm{C} \mathrm{NMR}\left(125 \mathrm{MHz}, \mathrm{CDCl}_{3}\right) \delta 176.5(\mathrm{C}-1), 175.2(\mathrm{C}-9)$, 106.5 (C-1'), 89.0 (C-5), 77.9 (C-3), 78.0 (C-6), 77.0 (C-
13), 75.2 (C-12), 71.2 (C-11), $70.6\left(\mathrm{C}-2^{\prime}\right), 70.1\left(\mathrm{C}-5^{\prime}\right), 65.7$ $\left(\mathrm{C}-3^{\prime}\right), 57.8\left(6-\mathrm{OCH}_{2} \mathrm{CH}_{3}\right), 44.4(\mathrm{C}-2), 43.3(\mathrm{C}-8), 43.1(\mathrm{C}-$ $10), 42.1(\mathrm{C}-7), 40.3\left[3^{\prime}-\mathrm{N}\left(\mathrm{CH}_{3}\right)_{2}\right], 28.1\left(\mathrm{C}-4^{\prime}\right), 15.9$ (6$\left.\mathrm{OCH}_{2} \underline{\mathrm{CH}}_{3}\right) 21.5(\mathrm{C}-14), 10.8\left(14-\mathrm{CH}_{3}\right)$.

$\mathrm{ES}^{+}-\mathrm{MS} m / z 619.5(\mathrm{M}+\mathrm{H})^{+}$

6-O-Allyl-3-O-decladinosyl-8a-aza-8a-homoerythromycin A (4c)

The title compound was prepared from $2 \mathbf{c}$ in $43.8 \%$ yield according to the procedure used to prepare $\mathbf{3 a}$.

${ }^{13} \mathrm{C}$ NMR $\left(125 \mathrm{MHz}, \mathrm{CDCl}_{3}\right) \delta 179.0(\mathrm{C}-1), 177.1$ (C-9), $135.2\left(6-\mathrm{OCH}_{2} \underline{\mathrm{CH}}=\mathrm{CH}_{2}\right), \quad 117.7 \quad\left(6-\mathrm{OCH}_{2} \mathrm{CH}=\underline{\mathrm{CH}}_{2}\right)$, 106.5 (C-1'), 88.7 (C-5), 81.8 (C-6), 79.0 (C-13), 78.4 (C3), 74.3 (C-11), 74.2 (C-12), 70.5 (C-2'), 69.9 (C-5'), 65.8 $\left(\mathrm{C}-3^{\prime}\right), 63.8\left(6-\mathrm{OCH}_{2} \mathrm{CH}=\mathrm{CH}_{2}\right), 46.1(\mathrm{C}-8), 44.3(\mathrm{C}-2)$, 41.6 (C-7), $40.3\left[3^{\prime}-\mathrm{N}\left(\mathrm{CH}_{3}\right)_{2}\right], 36.0$ (C-4), 33.0 (C-10), $28.3\left(\mathrm{C}-4^{\prime}\right), 20.9(\mathrm{C}-14), 10.9\left(14-\mathrm{CH}_{3}\right)$.

$\mathrm{ES}^{+}-\mathrm{MS} m / z 631.7(\mathrm{M}+\mathrm{H})^{+}$

6-O-Methyl-3-oxo-9a-aza-9a-homoerythromycin A (5a)

To a solution of 2'-O-acetyl-6-O-methyl-3-decladinosyl-9aaza-9a-homoerythromycin A (3a) $(0.760 \mathrm{~g}, 1.2 \mathrm{mmol})$ in $\mathrm{CH}_{2} \mathrm{Cl}_{2}(15 \mathrm{ml})$, DMSO $(1.27 \mathrm{ml})$ and $\operatorname{EDC}(1.34 \mathrm{~g}$, $7 \mathrm{mmol})$ were added. A solution of pyridine trifluoroacetate ( $1.37 \mathrm{~g}, 7 \mathrm{mmol})$ in $\mathrm{CH}_{2} \mathrm{Cl}_{2}(5 \mathrm{ml})$ was added dropwise within 30 minutes at $15^{\circ} \mathrm{C}$. After being stirred at room temperature for 3 hours, the reaction mixture was partitioned between $\mathrm{CH}_{2} \mathrm{Cl}_{2}$ and brine and extracted at $\mathrm{pH}$ 9.5 with $\mathrm{CH}_{2} \mathrm{Cl}_{2}(3 \times 20 \mathrm{ml})$. The organic extract was washed with brine and water, dried over $\mathrm{K}_{2} \mathrm{CO}_{3}$ and concentrated under reduced pressure. The oily residue was dissolved in $\mathrm{MeOH}(30 \mathrm{ml})$ and stirred at room temperature for 24 hours. After evaporation of $\mathrm{MeOH}$, the residue was purified by column chromatography $\left(\mathrm{CH}_{2} \mathrm{Cl}_{2}-\mathrm{MeOH}-\right.$ $\left.\mathrm{NH}_{4} \mathrm{OH}, 90: 9: 0.5\right)$ to give $\mathbf{5 a}$ in $83.1 \%$ yield.

$\mathrm{ES}^{+}$-MS $m / z 603.3(\mathrm{M}+\mathrm{H})^{+}$

By using this procedure $\left(2^{\prime}-O\right.$-acetylation, oxidation of $3-\mathrm{OH}$ and $2^{\prime}$-deacetylation), the compounds $\mathbf{5 b} \sim \mathbf{c}$ and $\mathbf{6 a} \sim \mathbf{c}$ were prepared.

6-O-Ethyl-3-oxo-9a-aza-9a-homoerythromycin A (5b)

The title compound was prepared starting from $\mathbf{3 b}$ in $31.4 \%$ yield.

$\mathrm{ES}^{+}-\mathrm{MS} m / z 617.4(\mathrm{M}+\mathrm{H})^{+}$

6-O-Allyl-3-oxo-9a-aza-9a-homoerythromycin A (5c)

The title compound was prepared starting from $3 \mathbf{c}$ in $20.6 \%$ yield.

$\mathrm{ES}^{+}-\mathrm{MS} m / z 629.4(\mathrm{M}+\mathrm{H})^{+}$ 
6-O-Methyl-3-oxo-8a-aza-8a-homoerythromycin A (6a)

The title compound was prepared starting from $\mathbf{4 a}$ in $82.9 \%$ yield.

$\mathrm{ES}^{+}$-MS $m / z 603.4(\mathrm{M}+\mathrm{H})^{+}$

6-O-Ethyl-3-oxo-8a-aza-8a-homoerythromycin A (6b)

The title compound was prepared starting from $\mathbf{4 b}$ in $34.3 \%$ yield.

$\mathrm{ES}^{+}$-MS $m / z 617.5(\mathrm{M}+\mathrm{H})^{+}$

6-O-Allyl-3-oxo-8a-aza-8a-homoerythromycin A (6c)

The title compound was prepared starting from $4 \mathbf{c}$ in $30.3 \%$ yield.

$\mathrm{ES}^{+}-\mathrm{MS} m / z 629.6(\mathrm{M}+\mathrm{H})^{+}$

6-O-Methyl-9a-aza-9a-homoerythromycin A 11,12-cyclic Carbonate (7)

To a solution of 1a $(3.0 \mathrm{~g}, 0.004 \mathrm{~mol})$ in EtOAc $(80 \mathrm{ml})$ ethylene carbonate $(9.0 \mathrm{~g}, 0.102 \mathrm{~mol})$ and $\mathrm{K}_{2} \mathrm{CO}_{3}(9.0 \mathrm{~g}$, $0.065 \mathrm{~mol}$ ) were added. After stirring at reflux temperature for 12 hours, the reaction mixture was diluted with EtOAC $(100 \mathrm{ml})$, washed with brine $(100 \mathrm{ml})$ and then with $\mathrm{H}_{2} \mathrm{O}$ $(100 \mathrm{ml})$. The evaporation of the organic solvent gave an oily residue, which was purified by silica gel column chromatography $\left(\mathrm{CH}_{2} \mathrm{Cl}_{2}-\mathrm{MeOH}\right.$ - conc. $\left.\mathrm{NH}_{4} \mathrm{OH}, 90: 9: 1.5\right)$ to afford 7 (2 g, 65\%).

${ }^{13} \mathrm{C}$ NMR (75 MHz, $\left.\mathrm{CDCl}_{3}\right) \delta 178.4(\mathrm{C}-9), 177.2(\mathrm{C}-1)$, $153.9\left(\mathrm{C}=\mathrm{O}\right.$ cyclic carbonate), $102.7\left(\mathrm{C}-1^{\prime}\right), 94.0\left(\mathrm{C}-1^{\prime \prime}\right)$, 84.7 (C-12), 83.6 (C-11), 79.1 (C-5), 78.7 (C-6), 77.9 (C4"), 75.5 (C-3), 75.2 (C-13), 72.6 (C-3"), $70.7\left(\mathrm{C}-2^{\prime}\right), 68.5$ $\left(\mathrm{C}-5^{\prime}\right), 65.3\left(\mathrm{C}-5^{\prime \prime}\right), 65.1\left(\mathrm{C}-3^{\prime}\right), 51.0\left(6-\mathrm{OCH}_{3}\right), 49.2\left(3^{\prime \prime}-\right.$ $\left.\mathrm{OCH}_{3}\right), 44.9(\mathrm{C}-2), 44.3(\mathrm{C}-10), 42.0(\mathrm{C}-4), 40.1$ [3'$\mathrm{N}\left(\mathrm{CH}_{3}\right)_{2}$ ], $39.4(\mathrm{C}-7), 36.2(\mathrm{C}-8), 34.3\left(\mathrm{C}-2^{\prime \prime}\right), 28.6\left(\mathrm{C}-4^{\prime}\right)$, 21.8 (C-14), $10.2\left(14-\mathrm{CH}_{3}\right)$.

$\mathrm{ES}^{+}-\mathrm{MS} m / z 789.8(\mathrm{M}+\mathrm{H})^{+}$

6-O-Methyl-8a-aza-8a-homoerythromycin A 11,12-cyclic Carbonate (8)

The title compound was prepared from $\mathbf{2 a}$ in $64.3 \%$ yield according to the procedure used to prepare 7 .

${ }^{13} \mathrm{C}$ NMR $\left(75 \mathrm{MHz}, \mathrm{CDCl}_{3}\right.$ ) $\delta 176.4(\mathrm{C}-1), 170.3(\mathrm{C}-9)$, $153.4\left(\mathrm{C}=\mathrm{O}\right.$ cyclic carbonate), $103.2\left(\mathrm{C}-1^{\prime}\right), 96.0\left(\mathrm{C}-1^{\prime \prime}\right)$, 85.6 (C-12), 82.2 (C-11), 80.2 (C-5), 79.8 (C-6), 78.0 (C4"), 77.0 (C-3), 75.7 (C-13), 72.8 (C-3"), $70.7\left(\mathrm{C}-2^{\prime}\right), 69.1$ $\left(\mathrm{C}-5^{\prime}\right), 65.6\left(\mathrm{C}-5^{\prime \prime}\right), 65.5\left(\mathrm{C}-3^{\prime}\right), 51.1\left(6-\mathrm{OCH}_{3}\right), 49.4\left(3^{\prime \prime}-\right.$ $\left.\mathrm{OCH}_{3}\right), 42.5$ (C-8), 42.4 (C-10), 42.3 (C-7), 42.3 (C-4), $40.3\left[3^{\prime}-\mathrm{N}\left(\mathrm{CH}_{3}\right)_{2}\right], 34.9\left(\mathrm{C}-2^{\prime \prime}\right), 28.8\left(\mathrm{C}-4^{\prime}\right), 22.5(\mathrm{C}-14)$, $10.5\left(14-\mathrm{CH}_{3}\right)$.

$\mathrm{ES}^{+}-\mathrm{MS} m / z 789.7(\mathrm{M}+\mathrm{H})^{+}$
6-O-Methyl-3-O-decladinosyl-9a-aza-9a-homoerythromycin A 11,12-cyclic Carbonate (9)

The title compound was prepared from 7 in $87.2 \%$ yield according to the procedure used to prepare $\mathbf{3 a}$.

The title compound was also prepared from 3a in $66.5 \%$ yield according to the procedure used to prepare 7 .

${ }^{13} \mathrm{C}$ NMR $\left(125 \mathrm{MHz}, \mathrm{CDCl}_{3}\right) \delta 177.0(\mathrm{C}-9), 176.2(\mathrm{C}-1)$, $153.4\left(\mathrm{C}=\mathrm{O}\right.$ carbonate), $106.3\left(\mathrm{C}-1^{\prime}\right), 87.9(\mathrm{C}-5), 85.4(\mathrm{C}-$ 12), 84.1 (C-11), 79.3 (C-6), 78.3 (C-3), 76.4 (C-13), 70.4 $\left(\mathrm{C}-2^{\prime}\right), 69.8\left(\mathrm{C}-5^{\prime}\right), 65.9\left(\mathrm{C}-3^{\prime}\right), 50.2\left(6-\mathrm{OCH}_{3}\right), 44.5(\mathrm{C}-2)$, 44.5 (C-10), $40.3\left[3^{\prime}-\mathrm{N}\left(\mathrm{CH}_{3}\right)_{2}\right], 39.8(\mathrm{C}-7), 36.8$ (C-4), 34.8 (C-8), 28.7 (C-4'), 22.0 (C-14), $10.3\left(14-\mathrm{CH}_{3}\right)$. IR $v_{\max }(\mathrm{KBr}) \mathrm{cm}^{-1} 3440,2974,2939,1822,1729,1650$, 1525, 1457, 1380, 1241, 1167, 1113, 1073, 1047, 983.

$\mathrm{ES}^{+}$-MS $m / z 631.4(\mathrm{M}+\mathrm{H})^{+}$

6-O-Methyl-3-O-decladinosyl-8a-aza-8a-homoerythromycin A 11,12-cyclic Carbonate (10)

The title compound was prepared from $\mathbf{8}$ in $85.5 \%$ yield according to the procedure used to prepare $\mathbf{3 a}$.

The title compound was also prepared from $4 \mathbf{a}$ in $51.2 \%$ yield according to the procedure used to prepare 7 .

${ }^{13} \mathrm{C}$ NMR $\left(125 \mathrm{MHz}, \mathrm{CDCl}_{3}\right) \delta 175.5$ (C-1), $170.4(\mathrm{C}-9)$, $153.1\left(\mathrm{C}=\mathrm{O}\right.$ carbonate), $106.9\left(\mathrm{C}-1^{\prime}\right), 91.7(\mathrm{C}-5), 86.8$ (C12), 82.9 (C-11), 79.1 (C-6), 76.8 (C-3), 74.8 (C-13), 70.4 $\left(\mathrm{C}-2^{\prime}\right), 69.8\left(\mathrm{C}-5^{\prime}\right), 65.5\left(\mathrm{C}-3^{\prime}\right), 49.3\left(6-\mathrm{OCH}_{3}\right), 43.9(\mathrm{C}-2)$, 43.8 (C-8), 42.5 (C-10), 41.1 (C-7), 40.2 [3'- ( $\left.^{\prime}\left(\mathrm{CH}_{3}\right)_{2}\right]$, 37.1 (C-4), 28.1 (C-4'), 22.2 (C-14), $10.2\left(14-\mathrm{CH}_{3}\right)$.

$\mathrm{ES}^{+}-\mathrm{MS} m / z 631.4(\mathrm{M}+\mathrm{H})^{+}$

6-O-Methyl-3-oxo-9a-aza-9a-homoerythromycin A 11,12cyclic Carbonate (11)

The title compound was prepared starting from 9 in $21.3 \%$ yield according to the procedure used to prepare $\mathbf{5 a}$.

${ }^{13} \mathrm{C}$ NMR (75 MHz, $\left.\mathrm{CDCl}_{3}\right) \delta 206.7(\mathrm{C}-3), 177.0(\mathrm{C}-9)$, 170.1 (C-1), $153.6(\mathrm{C}=\mathrm{O}$ carbonate $), 103.4\left(\mathrm{C}-1^{\prime}\right), 84.4$ (C-12), 84.1 (C-11), 78.5 (C-5), 78.1 (C-6), 75.7 (C-13), $70.1\left(\mathrm{C}-2^{\prime}\right), 69.2\left(\mathrm{C}-5^{\prime}\right), 65.4\left(\mathrm{C}-3^{\prime}\right), 50.1\left(6-\mathrm{OCH}_{3}\right), 50.0$ (C-2), 47.7 (C-4), 44.2 (C-10), 39.9 [3'-N( $\left.\left.\mathrm{CH}_{3}\right)_{2}\right], 39.1$ (C7), 36.2 (C-8), 28.0 (C-4'), $21.7(\mathrm{C}-14), 10.0\left(14-\mathrm{CH}_{3}\right)$.

$\mathrm{ES}^{+}-\mathrm{MS} m / z 629.5(\mathrm{M}+\mathrm{H})^{+}$

6-O-Methyl-3-oxo-8a-aza-8a-homoerythromycin A 11,12cyclic Carbonate (12)

The title compound was prepared starting from 10 in $56.6 \%$ yield according to the procedure used to prepare $\mathbf{5 a}$.

${ }^{13} \mathrm{C} \mathrm{NMR}\left(75 \mathrm{MHz}, \mathrm{CDCl}_{3}\right) \delta 203.0(\mathrm{C}-3), 171.1$ (C-9), $169.6(\mathrm{C}-1), 152.4(\mathrm{C}=\mathrm{O}$ carbonate $), 104.8\left(\mathrm{C}-1^{\prime}\right), 85.2$ (C-12), 82.6 (C-11), 82.6 (C-5), 81.1 (C-6), 75.9 (C-13), $70.2\left(\mathrm{C}-2^{\prime}\right), 69.8\left(\mathrm{C}-5^{\prime}\right), 65.9\left(\mathrm{C}-3^{\prime}\right), 52.7(\mathrm{C}-2), 49.1$ (6$\left.\mathrm{OCH}_{3}\right), 48.3(\mathrm{C}-4), 44.8(\mathrm{C}-8), 43.6(\mathrm{C}-10), 40.3$ [3'- 
$\left.\mathrm{N}\left(\mathrm{CH}_{3}\right)_{2}\right], 40.2$ (C-7), 28.4 (C-4'), 22.7 (C-14), 10.5 (14$\left.\mathrm{CH}_{3}\right)$. IR $v_{\max }(\mathrm{KBr}) \mathrm{cm}^{-1} 3379,2976,1814,1755,1713$, 1668, 1539, 1457, 1381, 1243, 1166, 1110, 1062, 995.

$\mathrm{ES}^{+}$-MS $m / z 629.6(\mathrm{M}+\mathrm{H})^{+}$

6-O-Methyl-3-O-decladinosyl-3- $O$-(4-nitrophenyl)acetyl9a-aza-9a-homoerythromycin A 11,12-cyclic Carbonate $\underline{(13)}$

To a solution of 4-nitrophenylacetic acid $(0.263 \mathrm{~g}$, $1.5 \mathrm{mmol})$ in dry $\mathrm{CH}_{2} \mathrm{Cl}_{2}(5 \mathrm{ml})$ and $\mathrm{Et}_{3} \mathrm{~N}(0.20 \mathrm{ml}$, $1.5 \mathrm{mmol})$ pivaloyl chloride $(0.18 \mathrm{ml}, 1.5 \mathrm{mmol})$ was added at $0^{\circ} \mathrm{C}$. After being stirred for 30 minutes, a solution of $2^{\prime}-$ acetyl protected $9(0.269 \mathrm{~g}, 0.4 \mathrm{mmol})$ in $\mathrm{CH}_{2} \mathrm{Cl}_{2}(2 \mathrm{ml})$ and pyridine $(0.4 \mathrm{ml})$ were added and the mixture was stirred for another 3 hours. The reaction mixture was partitioned between $\mathrm{CH}_{2} \mathrm{Cl}_{2}$ and brine, the layers were separated and the aqueous one extracted with $\mathrm{CH}_{2} \mathrm{Cl}_{2}(20 \mathrm{ml} \times 3)$. Combined organic extracts were dried, the solvent removed under reduced pressure and the residue left in $\mathrm{MeOH}$ $(30 \mathrm{ml})$ at room temperature overnight. Methanol was removed and the residue was purified by chromatography on silica gel, eluting with $\mathrm{CH}_{2} \mathrm{Cl}_{2}-\mathrm{MeOH}$ - conc. $\mathrm{NH}_{4} \mathrm{OH}$, $90: 9: 0.5$ to give $0.142 \mathrm{~g}(44.7 \%)$ of title compound 13 .

${ }^{13} \mathrm{C}$ NMR (125 MHz, $\left.\mathrm{CDCl}_{3}\right) \delta 177.1$ (C-9), $174.8(\mathrm{C}-1)$, 170.0 (3-OCO), $153.5(\mathrm{C}=\mathrm{O}$ carbonate), 147.3, 141.1, 130.5, $123.7(\mathrm{Ph}), 103.9\left(\mathrm{C}-1^{\prime}\right), 85.1$ (C-12), 84.0 (C-11), 81.3 (C-5), 79.3 (C-6), 77.8 (C-3), 76.3 (C-13), 70.4 (C-2'), $69.5\left(\mathrm{C}-5^{\prime}\right), 66.2\left(\mathrm{C}-3^{\prime}\right), 50.9\left(6-\mathrm{OCH}_{3}\right), 44.4(\mathrm{C}-10), 43.3$ (C-2), $41.2\left(\mathrm{CH}_{2}-\mathrm{Ph}\right), 40.4$ [3'-N( $\left.\left(\mathrm{CH}_{3}\right)_{2}\right], 39.4(\mathrm{C}-7), 37.8$ (C-4), 35.4 (C-8), 28.7 (C-4'), 22.0 (C-14), 10.4 (14- $\mathrm{CH}_{3}$ ). IR $v_{\max }(\mathrm{KBr}) \mathrm{cm}^{-1} 3417,3380,2975,2939,1813,1750$, 1669, 1524, 1526, 1458, 1348, 1167, 1076, 1046.

$\mathrm{ES}^{+}$-MS $m / z 794.3(\mathrm{M}+\mathrm{H})^{+}$

By using this procedure (2'-O-acetylation, 3-O-acylation with the corresponding carboxylic acid and pivaloyl chloride and $2^{\prime}$-deacetylation), compounds $\mathbf{1 4 \sim 1 6}$ and 18 232 were prepared.

6-O-Methyl-3-O-decladinosyl-3-O-(4-nitrophenyl)acetyl8a-aza-8a-homoerythromycin A 11,12-cyclic Carbonate (14)

Reaction of $\mathbf{1 0}$ with 4-nitrophenylacetic acid gave the title compound in $75.3 \%$ yield.

${ }^{13} \mathrm{C}$ NMR (125 MHz, $\left.\mathrm{CDCl}_{3}\right) \delta 173.5$ (C-1), $170.8(\mathrm{C}-9)$, 169.8 (3-OCO), 153.1 ( $\mathrm{C}=\mathrm{O}$ carbonate), 147.2, 141.2, 130.5, $123.7(\mathrm{Ph}), 103.9\left(\mathrm{C}-1^{\prime}\right), 88.9$ (C-12), 82.4 (C-5), 82.0 (C-11), 79.6 (C-6), 76.7 (C-3), 76.0 (C-13), 70.3 (C$\left.2^{\prime}\right), 69.6\left(\mathrm{C}-5^{\prime}\right), 66.9\left(\mathrm{C}-3^{\prime}\right), 50.7\left(6-\mathrm{OCH}_{3}\right), 43.8(\mathrm{C}-2)$, 43.1 (C-10), 43.0 (C-8), 41.7 (C-7), $41.2\left(\mathrm{CH}_{2}-\mathrm{Ph}\right), 40.3$ [3'-N( $\left.\left(\mathrm{CH}_{3}\right)_{2}\right], 38.4(\mathrm{C}-4), 28.3\left(\mathrm{C}-4^{\prime}\right), 22.3(\mathrm{C}-14), 10.2$ $\left(14-\mathrm{CH}_{3}\right)$.
$\mathrm{ES}^{+}-\mathrm{MS} m / z 794.4(\mathrm{M}+\mathrm{H})^{+}$

6-O-Methyl-3-O-decladinosyl-3-O-(4-chlorophenyl)acetyl8a-aza-8a-homoerythromycin A 11,12-cyclic Carbonate (15)

Reaction of $\mathbf{1 0}$ with 4-chlorophenylacetic acid gave the title compound in $68.5 \%$ yield.

${ }^{13} \mathrm{C}$ NMR (125 MHz, $\left.\mathrm{CDCl}_{3}\right) \delta 173.5(\mathrm{C}-1), 171.1$ (3OCO), 170.6 (C-9), 153.2 ( $\mathrm{C}=\mathrm{O}$ carbonate), 133.2, 132.3, 131.0, $128.8(\mathrm{Ph}), 102.7\left(\mathrm{C}-1^{\prime}\right), 86.3(\mathrm{C}-12), 82.3$ (C-5), 82.3 (C-11), 78.6 (C-6), 77.3 (C-3), 76.1 (C-13), 69.8 (C$\left.2^{\prime}\right), 68.4\left(\mathrm{C}-5^{\prime}\right), 66.4\left(\mathrm{C}-3^{\prime}\right), 50.7\left(6-\mathrm{OCH}_{3}\right), 43.7(\mathrm{C}-2)$, 42.8 (C-10), 42.8 (C-8), 41.8 (C-7), $40.8\left(\mathrm{CH}_{2}-\mathrm{Ph}\right), 40.5$ [3'-N $\left(\mathrm{CH}_{3}\right)_{2}$ ], 38.1 (C-4), $30.8\left(\mathrm{C}-4^{\prime}\right), 22.3(\mathrm{C}-14), 10.2$ $\left(14-\mathrm{CH}_{3}\right)$. IR $v_{\max }(\mathrm{KBr}) \mathrm{cm}^{-1} 3388,2976,2941,2883$, 2787, 1812, 1744, 1667, 1541, 1493, 1458, 1380, 1357, 1332, 1234, 1165, 1111, 1051, 1017, 981.

$\mathrm{ES}^{+}$-MS $m / z 783.3(\mathrm{M}+\mathrm{H})^{+}$

${ }^{13} \mathrm{C}$ NMR data for the compounds $\mathbf{1 6} \sim \mathbf{2 8}$ are presented in the Table 1.

6-O-Methyl-3-O-decladinosyl-3-O-(4-phenylbutyryl)-8aaza-8a-homoerythromycin A (16)

Reaction of 4a with 4-phenylbutyric acid gave the title compound in $25.0 \%$ yield.

$\mathrm{ES}^{+}$-MS $m / z 751.4(\mathrm{M}+\mathrm{H})^{+}$

6-O-Methyl-3-O-decladinosyl-3-O-(4-nitrophenylcarbamoyl)-8a-aza-8a-homoerythromycin A (17)

To a solution of $2^{\prime}$-acetyl protected $4 \mathbf{a}(90 \mathrm{mg}, 0.14 \mathrm{mmol})$ in DMF $(0.5 \mathrm{ml})$ and toluene $(0.5 \mathrm{ml})$ 4-aminophenyl isocyanate $(70 \mathrm{mg}, 4.2 \mathrm{mmol})$ was added. The solution was stirred under $\operatorname{argon}$ at $50^{\circ} \mathrm{C}$ for 4.5 hours and then at room temperature overnight. Water $(10 \mathrm{ml})$ was added and the product extracted with $\mathrm{CH}_{2} \mathrm{Cl}_{2}(2 \times 30 \mathrm{ml})$. Combined organic extracts were washed with brine $(15 \mathrm{ml})$, dried over $\mathrm{K}_{2} \mathrm{CO}_{3}$ and evaporated to dryness. The residue was purified by column chromatography (EtOAc - hexane $\left.\mathrm{Et}_{2} \mathrm{~N}, 60: 30: 0.2\right)$ yielding $95 \mathrm{mg}$ of $2^{\prime}$-acetyl protected 17 that after deprotection in $\mathrm{MeOH}(15 \mathrm{ml})$ at room temperature overnight gave the title compound $(81 \mathrm{mg}$, $71.2 \%)$.

$\mathrm{ES}^{+}$-MS $m / z 769.5(\mathrm{M}+\mathrm{H})^{+}$

6-O-Methyl-3- $O$-decladinosyl-3-O-(4-pyridin-3-yl-imidazol-1-yl)acetyl-8a-aza-8a-homoerythromycin A (18)

Reaction of 4a with (4-pyridin-3-yl-imidazol-1-yl)acetic acid gave the title compound in $45.1 \%$ yield.

$\mathrm{ES}^{+}-\mathrm{MS} m / z 790.4(\mathrm{M}+\mathrm{H})^{+}$ 
6-O-Methyl-3-O-decladinosyl-3-O-(pyridin-4yl-sulfanyl)acetyl-8a-aza-8a-homo-erythromycin A (19)

Reaction of 4a with (pyridin-4-yl)thioacetic acid gave the title compound in $30.0 \%$ yield.

$\mathrm{ES}^{+}$-MS $m / z 756.5(\mathrm{M}+\mathrm{H})^{+}$

6-O-Methyl-3-O-decladinosyl-3-O-(naphthalene-1-yl)acetyl-8a-aza-8a-homo-erythromycin A (20)

Reaction of 4a with (naphthalen-1-yl)acetic acid gave the title compound in $57.6 \%$ yield.

$\mathrm{ES}^{+}$-MS $m / z 773.6(\mathrm{M}+\mathrm{H})^{+}$

6-O-Methyl-3-O-decladinosyl-3-O-(4-nitrophenyl)acryloyl8a-aza-8a-homo-erythromycin A (21)

Reaction of 4a with 3-(4-nitrophenyl)acrylic acid gave the title compound in $22.0 \%$ yield.

$\mathrm{ES}^{+}$-MS $m / z 780.6(\mathrm{M}+\mathrm{H})^{+}$

6-O-Methyl-3- $O$-decladinosyl-3-O-(pyridin-3-yl)acetyl-8aaza-8a-homoerythromycin A (22)

Reaction of 4a with (pyridin-3-yl)acetic acid gave the title compound in $66.4 \%$ yield.

$\mathrm{ES}^{+}-\mathrm{MS} m / z 724.6(\mathrm{M}+\mathrm{H})^{+}$

6-O-Methyl-3- $O$-decladinosyl-3-O-(pyridin-4-yl)acetyl-8aaza-8a-homoerythromycin A (23)

Reaction of 4a with (pyridin-4-yl)acetic acid gave the title compound in $60.4 \%$ yield.

$\mathrm{ES}^{+}-\mathrm{MS} m / z 724.5(\mathrm{M}+\mathrm{H})^{+}$

6-O-Methyl-3-O-decladinosyl-3- $O$-(4-nitrophenyl)acetyl8a-aza-8a-homoerythromycin A (24)

Reaction of 4a with 4-nitrophenylacetic acid gave the title compound in $47.8 \%$ yield.

$\mathrm{ES}^{+}-\mathrm{MS} m / z 768.4(\mathrm{M}+\mathrm{H})^{+}$

6-O-Methyl-3-O-decladinosyl-3-O-[(5-quinolin-3-yl)pent3-enoyl]-8a-aza-8a-homo-erythromycin A (25)

Reaction of $\mathbf{4 a}$ with (5-quinolin-3-yl)pent-3-enoic acid gave the title compound in $60.1 \%$ yield.

$\mathrm{ES}^{+}-\mathrm{MS} m / z 814.7(\mathrm{M}+\mathrm{H})^{+}$

6-O-Methyl-3-O-decladinosyl-3-O-(4-methoxyphenyl)acetyl-8a-aza-8a-homo-erythromycin A (26)

Reaction of 4a with 4-methoxyphenylacetic acid gave the title compound in $51.4 \%$ yield.

$\mathrm{ES}^{+}$-MS $m / z 753.7(\mathrm{M}+\mathrm{H})^{+}$

6-O-Methyl-3-O-decladinosyl-3-O-(3-phenylpropionyl)-8aaza-8a-homoerythromycin A (27)

Reaction of 4a with 3-phenylpropionic acid gave the title compound in $61.5 \%$ yield.

$\mathrm{ES}^{+}$-MS $m / z 737.5(\mathrm{M}+\mathrm{H})^{+}$

6-O-Methyl-3-O-decladinosyl-3- $O$-phenylacetyl-8a-aza-8ahomoerythromycin A (28)

Reaction of 4a with phenylacetic acid gave the title compound in $46.6 \%$ yield.

$\mathrm{ES}^{+}$-MS $m / z 723.4(\mathrm{M}+\mathrm{H})^{+}$

6-O-Methyl-3-O-decladinosyl-3-O-(4-nitrophenyl)acetyl9a-aza-9a-homoerythromycin A (29)

Reaction of 3a with 4-nitrophenylacetic acid gave the title compound in $80.1 \%$ yield.

IR $v_{\max }(\mathrm{KBr}) \mathrm{cm}^{-1} 3396,2976,2941,2879,1732,1698$, 1669, 1601, 1521, 1456, 1380, 1346, 1232, 1182, 1111, 1073, 1051, 983.

$\mathrm{ES}^{+}-\mathrm{MS} m / z 768.4(\mathrm{M}+\mathrm{H})^{+}$

6-O-Ethyl-3- $O$-decladinosyl-3- $O$-(4-nitrophenyl)acetyl-9aaza-9a-homoerythromycin A (30)

Reaction of $\mathbf{3 b}$ with 4-nitrophenylacetic acid gave the title compound in $63.3 \%$ yield.

${ }^{13} \mathrm{C}$ NMR (125 MHz, $\left.\mathrm{CDCl}_{3}\right) \delta 177.4(\mathrm{C}-1), 170.2$ (3OCO), 170.0 (C-9), 147.0, 140.8, 130.5, 123.8 (Ph), 103.7 (C-1'), 81.8 (C-5), 80.1 (C-13), 80.0 (C-6), 78.8 (C-3), 74.4 (C-11), 74.1 (C-12), 70.5 (C-2'), $69.6\left(\mathrm{C}-5^{\prime}\right), 66.1\left(\mathrm{C}-3^{\prime}\right)$, $58.3\left(6-\mathrm{OCH}_{2} \mathrm{CH}_{3}\right), 45.8(\mathrm{C}-10), 42.7(\mathrm{C}-2), 41.4\left(\mathrm{CH}_{2}-\right.$ $\mathrm{Ph}), 41.2(\mathrm{C}-7), 40.4\left[3^{\prime}-\mathrm{N}\left(\mathrm{CH}_{3}\right)_{2}\right], 36.5$ (C-4), 33.2 (C-8), $28.8\left(\mathrm{C}-4^{\prime}\right), 15.8\left(6-\mathrm{OCH}_{2} \mathrm{CH}_{3}\right), 20.9(\mathrm{C}-14), 11.2(14-$ $\mathrm{CH}_{3}$ ).

$\mathrm{ES}^{+}$-MS $m / z 782.5(\mathrm{M}+\mathrm{H})^{+}$

6-O-Ethyl-3-O-decladinosyl-3-O-(4-nitrophenyl)acetyl-8aaza-8a-homoerythromycin A (31)

Reaction of $\mathbf{4 b}$ with 4-nitrophenylacetic acid gave the title compound in $39.7 \%$ yield.

${ }^{13} \mathrm{C}$ NMR $\left(125 \mathrm{MHz}, \mathrm{CDCl}_{3}\right) \delta 175.6(\mathrm{C}-9), 174.0(\mathrm{C}-1)$, 169.6 (3-OCO), 147.3, 141.2, 130.4, $123.8(\mathrm{Ph}), 104.1$ (C1'), 83.9 (C-5), 78.4 (C-6), 77.8 (C-3), 77.8 (C-13), 74.6 (C-12), 71.0 (C-11), 70.5 (C-2'), 69.8 (C-5'), 65.9 (C-3'), $58.4\left(6-\mathrm{OCH}_{2} \mathrm{CH}_{3}\right), 42.8$ (C-2), $42.4(\mathrm{C}-10), 41.8(\mathrm{C}-7)$, $41.6\left(\mathrm{C}-8, \mathrm{CH}_{2}-\mathrm{Ph}\right), 40.4\left[3^{\prime}-\mathrm{N}\left(\mathrm{CH}_{3}\right)_{2}\right], 37.6(\mathrm{C}-4), 28.6$ (C-4'), $15.8\left(6-\mathrm{OCH}_{2} \mathrm{CH}_{3}\right), 21.3(\mathrm{C}-14), 10.4\left(14-\mathrm{CH}_{3}\right)$.

$\mathrm{ES}^{+}$-MS $m / z 782.5(\mathrm{M}+\mathrm{H})^{+}$

3-O-Decladinosyl-3-O-(4-nitrophenyl)acetyl-8a-aza-8ahomo-erythromycin A (32)

Hydrolysis of 8a-aza-8a-homoerythromycin [18], according to the procedure for preparation of $\mathbf{3 a}$, resulted in 3-O-decladinosyl-8a-aza-8a-homoerythromycin [19] which reacted with 4-nitrophenyl acetic acid to give the title 
compound in $80.3 \%$ yield.

${ }^{13} \mathrm{C}$ NMR $\left(125 \mathrm{MHz}, \mathrm{CDCl}_{3}\right) \delta 175.7$ (C-9), 175.1 (C-1), 169.5 (3-OCO), 147.2, 141.4, 130.6, $123.7(\mathrm{Ph}), 104.2(\mathrm{C}-$ 1'), 87.4 (C-5), 79.3 (C-3), 77.8 (C-13), 75.1 (C-12), 74.0 (C-6), 70.6 (C-11), 70.4 (C-2'), 69.6 (C-5'), 65.2 (C-3'), 43.7 (C-2), 42.3 (C-10), 42.2 (C-7), 41.3 (C-8, $\left.\underline{\mathrm{CH}}_{2}-\mathrm{Ph}\right)$, $40.4\left[3^{\prime}-\mathrm{N}\left(\mathrm{CH}_{3}\right)_{2}\right], 37.9$ (C-4), $28.3\left(\mathrm{C}-4^{\prime}\right), 21.4$ (C-14), $11.0\left(14-\mathrm{CH}_{3}\right)$.

$\mathrm{ES}^{+}-\mathrm{MS} m / z 754.4(\mathrm{M}+\mathrm{H})^{+}$

Acknowledgements We would like to thank Mrs. Jadranka Ivetic, Bozica Skrinjar, Visnja Majzel and Dunja Tankovic for their excellent technical assistance.

\section{References}

1. Morimoto S, Takahashi Y, Watanabe Y, Omura S. Chemical modification of erythromycins. I. Synthesis and antibacterial activity of 6-O-methylerythromycin A. J Antibiot 37: 187-189 (1984)

2. Djokic S, Kobrehel G, Lazarevski G, Lopotar N, Tamburašev Z. Erythromycin Series. Part 11. Ring Expansion of Erythromycin A Oxime by the Beckmann Rearrangement. J Chem Soc Perkin Trans I 1986: 1881-1890 (1986)

3. Djokic S, Kobrehel G, Lopotar N, Kamenar B, Nagl A, Mrvos D. Erythromycin series. Part 13. Synthesis and structure elucidation of 10-dihydro-10-deoxo-11-methyl-11azaerythromycin A. J Chem Research (S) 1988: 152-153 (1988)

4. Neu HC. The crisis in antibiotic resistance. Science 257: 1064-1073 (1992)

5. Elliott RL, Pireh D, Nilius AM, Johnson PM, Flamm RK, Chu DTW, Plattner JJ, Or YS. Novel 3-deoxy-3descladinosyl-6- $O$-methyl erythromycin A analogues. Synthesis and in vitro activity. Bioorg Med Chem Lett 7: 641-646 (1997)

6. Denis A, Agouridas C, Auger JM, Beneddeti Y, Bonnefoy A, Bretin F, Chantot JF, Dussarat A, Fromentin C, D'ambrieres SG, Lachaud S, Laurin P, Martret OL, Loyau V, Tessot N, Pejac JM, Perron S. Synthesis and antibacterial activity of HMR 3647 a new ketolide highly potent against erythromycin-resistant and susceptible pathogens. Bioorg Med Chem Lett 9: 3075-3080 (1999)

7. Or YS, Clark RF, Wang S, Chu DTW, Nilius AM, Flamm RK, Mitten M, Ewing P, Alder J, Ma Z. Design, synthesis and antimicrobial activity of 6-O-substitutes ketolides active against resistant respiratory tract pathogens. J Med Chem 43: 1045-1049 (2000)
8. Clark RF, Ma Z, Wang S, Griesgraber G, Tufano M, Yong H, Li L, Zhang X, Nilius AM, Chu DTW, Or YS: Synthesis and antibacterial activity of novel 6-O-substituted erythromycin A derivatives. Bioorg Med Chem Lett 10: 815-819 (2000)

9. Djokic S, Tamburasev Z. 9-Amino-3-O-cladinosyl-5-Odesosaminyl-6,11,12-trihydroxy-2,4,6,8,10,12-hexamethylpentadecane-olide. Tetrahedron Lett 17: 1645-1647 (1967)

10. Fernandes PB, Baker WR, Freiberg LA, Hardy DJ, Mcdonald EJ. New macrolides active against Streptococcus pyogenes with inducible or constitutive type of macrolidelincosamide-streptogramin B resistance. Antimicrob Agents Chemother 33: 78-81 (1989)

11. Murphy HW, Stephens VC, Conine JW (Eli Lilly). Erythromycin derivative and process for the preparation thereof. U.S. 3,417,077, Dec. 17 (1968)

12. Djokic S, Kobrehel G, Lazarevski G. Erythromycin series. XII. Antibacterial in vitro evaluation of 10-dihydro-10deoxo-11-azaerythromycin A: Synthesis and structureactivity relationship of its acyl derivatives. J Antibiot 40: 1006-1015 (1987)

13. Tanikawa T, Asaka T, Kashimura M, Suzuki K, Sugiyama H, Sato M, Kameo K, Morimoto S, Nishida A. Synthesis and antibacterial activity of a novel series of acylides: 3-O-(3pyridyl)acetylerythromycin A derivatives. J Med Chem 46: 2706-2715 (2003)

14. Periti P, Mazzei T, Mini E, Novelli A. Clinical pharmacokinetic properties of the macrolide antibiotics. Effects of age and various pathophysiological states (Part I). Clin Pharmacokinet 16(4): 193-214 (1989)

15. Williams JD, Sefton AM. Comparison of macrolide antibiotics. J Antimicrob Chemother 31 (Suppl. C): 11-26 (1993)

16. Baker WR, Clark JD, Stephens RL, Kim KH. Modification of macrolide antibiotics. Synthesis of 11-deoxo-11(carboxyamino)-6-O-methyl-erythromycin A 11,12-(cyclic esters) via an intramolecular Michael reaction of $O$ carbamates with an alpha, beta-unsaturated ketone. J Org Chem 53: 2340-2345 (1988)

17. Methods for dilution antimicrobial susceptibility tests for bacteria that grow aerobically, Approved standard, 5th Ed. NCCLS, M7-A5: 20 (2)

18. Wilkening RR, Ratcliffe RW, Doss GA, Bartizal KF, Graham AC, Herbert CM. The synthesis of novel 8a-aza-8ahomoerythromycin derivatives via the Beckmann rearrangement of 9(Z)-erythromycin A oxime. Bioorg Med Chem Lett 3: 1287-1292 (1993)

19. Alihodzic S, Kobrehel G, Lazarevski G, Mutak S, Stimac V, Pavlovic D, Fajdetic A. Synthesis of 3-acyl and 3-carbamoyl derivatives of 15-membered lactams. Book of Abstracts of 19th Croatian Meeting of Chemists and Chemical Engineers, Opatija, Croatia, April 24-27, 2005, p. 151 